discussion papers

FS IV $02-07$

On the Politics of the Regulatory Reform:

Econometric Evidence from the OECD

Countries

Tomaso Duso

March 2002

ISSN Nr. 0722 - 6748

Forschungsschwerpunkt

Markt und politische Ökonomie

Research Area

Markets and Political Economy 
Zitierweise/Citation:

Tomaso Duso, On the Politics of the Regulatory Reform:

Econometric Evidence from the OECD Countries,

Discussion Paper FS IV 02-07, Wissenschaftszentrum Berlin, 2002.

Wissenschaftszentrum Berlin für Sozialforschung gGmbH,

Reichpietschufer 50, 10785 Berlin, Germany, Tel. (030) $25491-0$

Internet: www.wz-berlin.de 


\section{ABSTRACT \\ On the Politics of the Regulatory Reform: Econometric Evidence from the OECD Countries*}

by Tomaso Duso

This paper empirically investigates contrasting views on the politics of economic policy. Merging different databases, we test various predictions coming form different strands of literature, with the aim of explaining the cross-sectional and temporal variation in the degree of regulatory intervention and entry liberalization in the digital mobile telecommunications industry of OECD countries during the 1990's. We analyze the role of political institutions, government's types and ideological position, industry and consumers' private interests, as well as the regulatory environment in shaping regulatory policy. We find strong evidence that all these sets of variables help to explain some degree of variability in the observed liberalization patterns among countries. Yet, political and regulatory institutions and the pressure of strong incumbent firms are found to be the most important factors.

Keywords: Political Economy, Regulation, Entry Liberalization, Institutions, Ideology, Private Interests, Mobile Telecommunications, OECD

JEL Classification: C23, D72, D78, L5

* I am very grateful to Thomas Cusack and to Lars-Hendrik Röller for useful discussions. Martina Samwer provided excellent research support in building the database. I thank the seminar participants at the WZB and for their useful comments. Financial support through the Deutsche Forschungsgemeinschaft (DFG) grant number Ro 2080 / 4-1 is gratefully acknowledged. All remaining errors are mine. 


\section{Zur Politik der Regulierungsreform: Ökonometrische Evidenz für OECD-Länder}

In diesem Beitrag werden verschiedene Theorieansätze zur Wettbewerbspolitik am Beispiel der Deregulierung der Mobilfunksindustrie in OECD-Ländern empirisch getestet. Die Rolle der politischen Institutionen, der Regierungstypologie und ihrer ideologischen Positionierung im politischen Spektrum, der privaten Interessen der Industrie und Konsumenten, sowie der Struktur von Regulierungsbehörden wird anhand einer neu entwickelten Datenbank untersucht, um die beobachte Variabilität in der Deregulierungspolitik zwischen OECD-Ländern zu erklären. Es wird gezeigt, dass alle diese verschiedene Faktoren die Deregulierung der Mobilfunksindustrie in OECDLänder während der 90er Jahren signifikant beeinflusst haben. Die Struktur der politische Institutionen und Regulierungsbehörden sowie der Druck starker Unternehmen im Markt sind jedoch die entscheidenden Faktoren des Deregulierungsprozesses. 
"Economic deregulation [...] is one of the most important experiments in economic policy of our time." Winston (1993, p.1262)

\section{Introduction}

In the past 20 years, the majority of industrialized countries have experienced an era of deregulation. Many industries, which for decades were guided by the state's hand, have been opened up to competition. Especially in the so called network industries - such as the telecommunications, airline, post, and electricity industries - the market structure and regulatory instruments have been widely reformed. ${ }^{1}$ On the one hand, governments have implemented more competitive market structures through the liberalization of entry and the privatization of the typically state owned incumbent operators, while on the other hand, following the developments in the economic literature, new regulatory designs were introduced with the aim of improving the effectiveness and efficiency of governmental intervention in the market. ${ }^{2}$

The speed, timings, and extent of these reforms among OECD countries, however, have been remarkably different. Why did some countries liberalize more and quicker? What have been the determinants of such reforms? We answer these questions by analyzing some new data on the regulatory reform undertaken during the 1990's in the OECD countries. The analysis that we will propose is essentially positive and descriptive, but we acknowledge that a deeper understanding of the process underling the regulatory reform is essential for a correct understanding of the effects of such reform, since effects and determinants of regulation should be simultaneously considered. ${ }^{3}$

According to the "public interest" view of public policy, one should observe regulation because market failures generate inefficiencies, which could be alleviated through the benevolent governmental intervention. ${ }^{4}$ Following the path breaking contribution by Stigler (1971), many scholars criticized this approach as unrealistic, and questioned the appropiateness of assuming a benevolent government. ${ }^{5}$ The alternative view interprets that regulation is essentially a redis-

\footnotetext{
${ }^{1}$ See for instance Bergman et al. (1998), a report on the developing of European deregulation especially concerning the telecommunications industry. For a survey on the history of deregulation see Winston (1993) and Chang (1997).

${ }^{2}$ As Winston (1993) pointed out, the role of economic research in the field of regulation has been crucial. He noted (p.1263): "deregulation would never have occurred if economists - especially microeconomists - had not generally supported it through their research."

${ }^{3}$ See Duso (2001) and Duso and Röller (2001) for a deeper analysis of this point.

${ }^{4}$ The 'welfare economics' approach to government intervention is essentially normative, but it would entails a positive theory of government under particularly strong assumptions such as complete information and the absence of transaction costs (Noll 1989).

${ }^{5}$ Actually, this critique to the welfare economic approach dates back at least to Buchanan and Tullock (1962)?.
} 
tributive process among self interested subjects who want to gain specific benefits by the means of governmental intervention.

Although some contributions have exploited the role of different political factors in shaping the regulatory policy, a well defined micropolitically founded theory of regulation has not yet been fully developed. Nevertheless, there exists a new and fast growing literature on the political microfoundation of economic policy - what Persson and Tabellini (2000) call political economics - which is closely related to and shall be helpful when trying to reach a deeper understanding of the politics of regulatory policy. ${ }^{6}$ During the 1990's, plenty of political economy models have been developed, each focusing on particular issues of the "political game" with the aim of determining how different factors influence economic policy. The role of political institutions, of the governments types and viability, of the politicians' ideological and programmatic positions, of the private interests and of the lobbying activity by pressure groups, of the regulatory agencies' institutional design were analyzed.

Following this renewed theoretical interest, the empirical literature on the politics of economic policy has found a new impulse as well, but it still remains at its infancy. In this paper we provide a comprehensive glance at new data on international regulation, thereby contributing to the debate on the politics of the regulatory reform by offering some new and robust stylized facts. We adopt a reduced form empirical approach to explain the cross-sectional and time-series variation in the degree of liberalization and regulation of the mobile telecommunications industry of the OECD countries during the 1990's. Merging different data bases, we empirically analyze predictions stemming from a rather heterogenous literature, aiming at "testing" which of these approaches can better explain the observed regularities. We uncovered a number of stylized facts about the (de)regulation of the mobile telecommunications industry. So, we show that majoritarian countries, countries with more accountable regulators, and countries with rightwing governments liberalized more, whereas countries with proportional electoral systems or consensus-type of democracies, with a presidential regime, with coalition rather than one-party governments, and with a strong incumbent firm liberalized less.

The paper proceeds as follows: Section 2 provides a brief review of the related literature. In Section 3, we provide a theoretical framework for our analysis by introducing political and economic factors which have been proposed as explanatory variables for regulatory policy. Section 4 deals with the description of our database obtained by merging many different sources. Section 5 presents our main model and discusses some methodological problems. We comments the results in Section 6 and conclude the paper in Section 7, where we present summary remarks and suggest directions for future research.

\footnotetext{
${ }^{6}$ See also Grossman and Helpman (2001) for a microfoundation of economic policy.
} 


\section{$2 \quad$ Related Literature}

The starting point for our review of the literature on the political economy of regulation, is the private interest view, also known as the economic theory, of regulation (Stigler, 1971). This approach stresses the role of interest groups in determining governmental intervention. Regulation is seen as a political process, whose structure has though not been formally modeled, in which specific interests express their demand for political intervention as a way of redistributing rents to themselves. ${ }^{7}$ The presence of market failures generates these rents, and their distribution among the different represented subjects depends on their relative strength (Peltzam, 1976) ${ }^{8}$ The consequent redistribution can be efficient if all interests are equally represented (Becker, 1983). ${ }^{9}$ This theory predicts that different groups in the population should try to "capture" the regulatory agency. ${ }^{10}$ Therefore, one should expect to observe variables related to these interest groups, their strength, size, and organization to significantly influence the observed regulatory pattern. ${ }^{11}$

The economic theory of regulation suffers however from several pitfalls. The first problem concerns its failure to model the political process through which the private interests are materialized in particular policy prescriptions. Essentially, the supply side of regulation is taken as exogenous, like a black box through which the demand for regulation is transformed in outcome. Yet, the supply side of the market for regulation, namely the entire public sector policy-making technology (politicians, governments, legislators, regulatory agencies, courts...), must be considered in a micropolitically founded theory of governmental intervention, since these actors create, shape, and monitor the regulatory process. ${ }^{12}$

\footnotetext{
${ }^{7}$ Stigler's definition of economic regulation was quite broad, essentially including all economic acts of the government.

${ }^{8}$ The original Stiglerian approach was a one-way capture theory: industry interests are the sole ones to be represented in the political outcome. Peltzman (1976) went beyond this simple capture theory, and stressed the role of the regulator as the institution that mediates between consumers' and producers' interests. Finally, Becker (1983) extends this dichotomous trade-off to the case of competition among interest groups.

${ }^{9}$ Bernheim and Whinston (1986a) formalized the lobbying process through an agency framework, in which the represented interests placed bids contingent to their favorable policy outcome. This model was applied in several studies to explain economic policy. For instance, Grossman and Helpman (1994) analyzed trade protection in such a framework; the predictions of their model have been very successfully supported by the empirical evidence (Goldberg and Maggi, 1999 and Gawande and Bandyopadhyay, 2000).

${ }^{10}$ See also Laffont and Tirole (1991) and (1993) for a theory of regulatory capture. Their focus is, however, on the optimal agency design in a world with asymmetric information.

${ }^{11}$ For empirical analyses of interest groups' pressure on regulatory decisions see Kroszner and Strahan (1999) and Duso (2001). See also Potters and Sloof (1996) for an excellent survey of the empirical literature on interest groups' influence.

${ }^{12}$ The political theory of economic policy recently proposed by Laffont (1999), which bases on the well developed incentive or principal-agent theory, may be seen as a possible way to formalize the supply side of regulation.
} 
Recently, a new theoretical and empirical literature in economics has dealt with the analysis of the role of political institutions in shaping economic policy. ${ }^{13}$ For instance, it has been shown theoretically as well as empirically that the regime type and the electoral rules not only shape government size and expenditures (Persson and Tabellini, 1999, 2001, Milesi-Ferretti et al. 2001, Lizzeri and Perisco, 2001), but also the tax rate and income distribution (Austen-Smith, 2000). In this study, we apply this kind of thinking to regulatory policy, because the rational of the aforementioned literature, namely that the conflict redistribution among different interested agents (and thus the policy's determination) depends on political institutions, should also hold for this regulatory governmental interventions, even if a well specified theoretical model has not been developed yet.

The second pitfall of the private interest theory of regulation is that it has been very successful in explaining regulatory intervention but, as many authors pointed out (see for instance Peltzman, 1989 and Noll, 1989), has failed to explain the deregulation process, a phenomenon that, from the 1980's onwards, has been widely observed in many industries and countries. One possible alternative approach, which has been stressed in political science, is that the ideological position of the policy makers also matters for policy determination (Kalt and Zuppan, 1984 , Hibbs, 1987a and 1987b, Poole and Rosenthal, 1993, Alesina, 1987?, Alesina and Rosenthal, 1995, Irwin and Kroszner, 1999). Although it may be problematic to consider the ideological position of politicians and voters as an exogenous determinant of economic policy (Poole and Rosenthal, 1993), we are interested in analyzing whether there exists any kind of relationship among these issues.

Finally, the private interest theory of regulation, by implicitly assuming that the regulator is a mere and neutral reflection of the political process generated by the legislator, denies the agency problem entailed in this relationship. However, as the following quote from Noll (1989, p.1255) points out, the organization of the regulatory process is surely an important factor to account for:

"Regardless of the motives of political actors, an essential ingredient to a theory of regulatory policy when the Coase theorem fails [i.e. when there are imperfect information and transaction costs] is how political officials control agencies. Whether the aim of regulation is to maximize efficiency or to transfer wealth to a special interest, politicians face a principal-agent problem in trying to assure reasonable bureaucratic compliance with the objectives behind a legislative mandate."

This agency problem behind the regulatory structure has been thoroughly analyzed in the literature (see among others Baron, 1988, Spiller, 1990, Laffont and Tirole, 1990 and 1991, Laffont,

\footnotetext{
${ }^{13}$ Political scientists have much thoroughly analyzed the role that political institutions have in shaping policy formation. See for instance Lijphart (1999).
} 
1996 and 1999, Estache and Martimort, 1998, Laffont and Martimort, 1999 , Faure-Grimaud and Martimort, 2000). ${ }^{14}$ Among other elements this view stresses that the independence, accountability, and transparency of the regulatory process are important factors, which could help to explain the role of the agency relations between the different subjects (Neven et al., 1993).

At this point, we have predictions coming from a rather heterogenous literature that have dealt, in the last 30 years, with the intriguing topic of the politics of regulation or, more generally, of economic policy. The contribution of this paper is to take some of these predictions to an empirical test, using a particularly suitable and new data set.

There are two recent papers, which are very closely related to our approach both in their motivation and in their econometric analysis. Djankov et al. (2001) analyzed the regulation of the entry of start-up firms in 75 countries. Their analysis concentrated on the bureaucratic requirements that a firm has to accomplish in order to set up a new business. They contrasted the predictions from different theoretical approaches and tested them on new data collected by the World Bank. The main results of the paper are that the public interest view of regulation is rejected by the data, the Stiglerian Approach finds some support, whereas a "tollbooth view" of economic policy - where regulation is pursued for the benefits of politicians and bureaucrats (De Soto, 1990) - seems to explain the cross-sectional variation in the costs and time necessary to start-up a new business much better.

$\mathrm{Li}$ et al. (2001) is a cross-sectional empirical analysis of the political economy of privatization and competition, which uses a new data set on the telecommunications sector built from different sources like the World Bank, Pyramid, and the ITU (International Telecommunications Union). They also adopted a reduced form approach basing on a generalized private-interest framework, and concentrating on the role that interest groups have in shaping the regulatory process. This theory seems to receive reasonably strong support from the data. Furthermore, since the data set contains many countries, they could contrast the experiences in democratic vs. non-democratic countries, in order to assess the role of democracy in shaping private interests' ability to influence the policy reform.

Both studies, which surely are an important step in filling the lack of empirical research on the political economy of the regulatory reform, do not investigate the role of political and regulatory institutions. ${ }^{15}$ As stressed by other authors (Noll, 2001, Levy and Spiller, 1996) institutions in place and the rules governing the decision making process play a crucial role in that they constrain the set of policy choices, and thus, determine the outcome of the reform process (McCubbins et al., 1989 ).

Also relevant for our research are a set of recent OECD working papers (Boylaud and Nico-

\footnotetext{
${ }^{14}$ Fiorina (1982) proposed an alternative approach to the delegation of regualtory authority based on the uncertainty about costs and benefits of regulation.

${ }^{15}$ See also Pryor (2000) for an empirical analysis of governmental regulation in OECD countries.
} 
letti, 2000, Gonec, Maher, and Nicoletti, 2000, and Nicoletti, 2001). While they are closely related to our work because they use some of the data that we use, they differ in their aim, since they analyze the effects rather than the determinants of regulatory reform. ${ }^{16}$ The main message of these studies is that the observed reforms of the regulatory environment could contribute substantially to improve economic performance (see also Noll, 2001 on this point), but that a large scope for further reform exists. Our paper will build a counterpart to these studies based on the political economy view, as a first step of a more ambitious research program in which determinants and effects of regulatory reforms are being simultaneously analyzed (Duso, 2001 and Duso and Röller, 2001).

One last comment is to be made at this point. The term regulation has been intentionally used rather generally during this introductory discussion. In the following sections, we shall be more precise about what we mean by regulatory reform, especially when we describe our data. This is also important because it is recognized that the politics of regulation and deregulation can be different (Winston, 1993). On the other hand, what we attempt in this Section is to think in quite general terms about the politics of the regulatory process, which entails regulation, re-regulation, and also deregulation. We believe, in fact, that a political economy theory of regulation should be able to encompass all these processes.

\section{Theoretical Motivation}

The approach that we take in this paper is empirical and consists in the estimation of reduced form relationships with a descriptive aim. We will not structurally test one particular theory, but rather we want to ask, looking at new data, whether different sets of political variables systematically influenced the regulatory process undertaken in the telecommunications industry during the 1990's in most of the OECD countries. We are looking for some stylized facts that help us to understand which political factors drove this reform process. In this Section, we present some theoretical background for our empirical analysis.

First we analyze the role of political institutions - such as the electoral rule and the political regime - that are shown to play a crucial role in shaping economic policy. A second set of explanatory variables is related to the government's political viability. Even though the government's and parliament's features are a by-product of the constitutional design, we are still interested to see whether these characteristics shape the ability to perform regulatory reforms. Then, we will consider variables related to partisan policy formation as expressed by the programmatic position of the government's parties on specific public policy issues, as well as by the

\footnotetext{
${ }^{16}$ See also Gruber and Verboven (2001) on the effects of entry and standard regulations on the evolution of cellular markets.
} 
government's position on the right-left dimension. We then investigate, in the Chicago School's tradition, whether the industry's private interests were materialized in policy prescriptions. And finally, we question whether the regulatory institutional environment shapes the policy making process. In this Section, we derive hypotheses from the theoretical literature that we will test with the data.

\subsection{Regulation, Institutions, and the Government}

Political scientists have focused on the analysis of the role of political institutions in shaping political phenomena. Recently, this "comparative policy approach" has also been used in economics in order to analyze the role of political institutions in shaping economic policy. ${ }^{17}$ As noted by Austen-Smith (2000, p.1257):

"[..] political "institutions matter" because the institutional differences are reflected in differences in the incentives of political agents to appeal to particular groups of voters who typically have distinct economic opportunities and, therefore, distinct preferences over economic policy."

Persson and Tabellini (1999) and (2001), Persson (2001) and Milesi-Ferretti et al. (2001) have theoretically and empirically analyzed whether the electoral rule and regime type influence fiscal policy and public spending. Their empirical findings, which are mainly based on their theoretical results, suggest that political institutions shape economic policy.

Yet no developed theoretical model suggests a systematic microfounded relationship between regulatory intensity and the institutions in place, even though some political models of regulation have already stressed the importance of the structure of the decision making and, in particular, the agency problem between different government and bureaucracy levels. ${ }^{18}$ We believe that some new empirical evidence, such as stylized facts, will help in deepening our understanding of these phenomena, and perhaps will stimulate a renewed theoretical discussion on this topic.

One characteristic of the telecommunications industry is that the range of users covers almost the entire population. This could imply that the regulation of utilities is a policy that interest a large base of voters, hence it might be considered to be a broad policy program. While this seems

\footnotetext{
${ }^{17}$ The comparative policy approach is positive and aims at comparing different equilibrium outcomes derived under different assumptions about the political institutions in place, which are considered to constitute the exogenous "rules of the game". Differently, the approach taken by Laffont (1999) is normative and aims at endogenising the institutional details, under the assumption of the existence of a "benevolent dictator", who optimally designs institutions under imperfect information.

${ }^{18}$ See Levy and Spiller (1996) for an interesting but less formal analysis of the impact of political and social institutions on regulatory structure and performance. See also Noll (2001) on the politics of regulatory reform in developing countries, and Laffont and Tirole (1990) and (1991) for more formal analyses.
} 
to be plausible for the wireline telecommunications industry, it may be much less true for the cellular telecommunications industry, especially in its early phase, during which cellular services were still not extensively adopted. There are then some specific group of the population - namely business and young people - which mostly benefit from a competitive mobile telecommunications industry. In our empirical analysis, we concentrate on the mobile telecommunications' entry regulation or liberalization, thus we assume that this kind of policy is perceived to be a targeted policy.

From the theoretical literature mentioned above, we borrow the idea that countries with majoritarian elections should be expected to implement more specific and targeted policies. This is because smaller districts, which are generally associated with this kind of electoral rule, foster more competition to capture the support of particular voters. This prediction should also be reinforced by the fact that politicians internalize less of the positive effect of a broad program, since the electoral districts in majoritarian elections are smaller. Our first prediction is that in the mobile telecommunications industry one should observe more liberalization in majoritarian than in parliamentarian regimes.

It is harder to make a clear cut prediction for the second kind of institutional detail: the regime type. One of the major differences among different regime types concerns the separation of powers. Presidential regimes are usually associated with a strong division of power between parliament and government. In presidential regimes the government is normally more accountable and can less easily abuse its power (Persson et al., 1997). An implication of this is that in a presidential regime, since there is a relatively less stable majority of legislators that pursue the interests of the majority of voters, the opposing interests of smaller minorities may compete with each other, leading as a result to the choice of broader programs (Persson, 2001). Stretching this conclusion perhaps too much, we would then expect to observe less liberalization in the mobile phone market in presidential regimes.

Hypothesis 1 If mobile telecommunications' entry liberalization is perceived as a targeted policy program, countries with majoritarian elections should liberalize more, whereas presidential regimes should liberalize less.

However, one should be cautious to extend the predictions stemming from the model developed in public finance to the regulatory reform case. First, because as we saw it is difficult to assess how targeted this policy intervention should be considered, and second, because we cannot be sure that the mechanisms driving the results in the public finance models also hold in a political economy model of regulation.

Since the dichotomous representation - majoritarian vs. proportional elections and presidential vs. parliamentary regimes - seems to be too simplistic to account for the enormous 
variety of a country's formal and informal institutions, and in order to improve the quality of our analysis, we will use also other measures of political institutions. In his influential study on democracy, Arend Lijphart (1999) showed that democracy's typologies can be reduced to a clear two-dimensional pattern along two institutional dimensions: the executives-parties dimension and the federal-unitary dimension. ${ }^{19}$ Both indexes tell how majoritarian and how consensual countries are along the two chosen dimensions, which account for the division of powers between government and parliament (executive-party) and between different level of governments (federal-unitary). Compared to the previously presented institutional dummies, these two new variables are a metric measure of institutions, that entails richer information.

In this case, we do not have a microfounded model which predicts how these institutional details impact on policy. ${ }^{20}$ Yet, there exists some literature in political science, which stresses the role of veto players in influencing policy reform. In particular, Tsebelis (1995) showed that the potential of policy change decreases with the number of veto players. ${ }^{21}$ Since more majoritarian regimes in Lijphart's sense face less veto players in both dimensions, the prediction should be that majoritarian democracies should be better able than consensual democracies to implement policy reform.

Hypothesis 2 More majoritarian democracies along the executive-party and the federal-unitary dimensions are expected to be more effective than consensual democracies in implementing policy reform.

A second kind of institutional variables that one can consider is related to the government's type. This institutional detail is of course related to the electoral system as well as to the regime type of which it is a by-product. Nevertheless we still want to analyze whether they have a direct impact on regulatory policy. We consider two different government types: one-party vs. coalition governments. ${ }^{22}$ Moreover, we want to observe whether the government's political support and the opposition's fractionalization play a role in shaping the economic policy. In fact whether a government is viable, i.e. able to effectively govern and implement policies that depart

\footnotetext{
${ }^{19}$ The two indexes were obtained by aggregating through factor analysis information about ten different political dimensions. We refer interested readers to Lijphart's book for a very clear and deep analysis.

${ }^{20}$ Lijphart (1999) showed that these measures of consensus democracy have a significant impact on many macroeconomic performance variables. In particular, he showed that consensus democracies have done better than majoritarian democracies, especially with regard to the control of inflation.

${ }^{21} \mathrm{He}$ also showed that the potential for policy change decreases with the incongruence and with the internal coehesion of veto players.

${ }^{22}$ As Alesina and Rosenthal (1995) stressed, the dichotomy "one party vs. coalition government" in parliamentary democracies parallels the idea of "unified vs. divided government" in presidential systems. The division of power can be used by voters to assure a moderation of the government's policy. Moreover, coalition governments, having more veto players, should face a more persistent status quo bias (Alesina and Drazen 1991) .
} 
from the status quo, also depends upon the composition of the legislature, and in particular on how strongly the government is supported in the legislature. ${ }^{23}$ We can than state the following claim:

Hypothesis 3 Coalition governments are expected to push the regulatory reform and the liberalization process less than one-party government.

\subsection{Ideology and Partisan Politics}

In the partisan politics tradition, politicians or political parties choose their policies not only in order to be reelected like in the electoral competition models, but rather because they care about the policy outcome as well. This implies that the platforms of the different politicians may not converge to the median voter's preferred policy, and may instead be driven by partisan preferences, which should represent the interests of their constituencies (Alesina and Rosenthal, 1995).

Although many scholars argue that in modern industrialized countries ideology has lost its role in shaping policy, there exists some evidence that partisanship matters, although it is not always clear how it matters. Poole and Rosenthal (1993) showed that the roll call voting in the U.S. Congress is very well explained by ideology as expressed by the unidimensional "liberal-conservative" measure and, furthermore, that such dimension is intertemporally stable. ${ }^{24}$ Rosenthal and Romer (1987) gave some examples of how this unidimensional measure of ideology is well in line with the Congress' voting behavior on specific regulatory issues. Extending these arguments to a cross-sectional comparison across countries, we argue that the "right-left" dimension should also explain regulatory patterns in OECD countries. ${ }^{25}$

Hypothesis 4 We expect to observe that left-wing governments tend to liberalize less than rightwing governments. ${ }^{26}$

\footnotetext{
${ }^{23}$ As we already mentioned, according to the existing empirical evidence, regulatory policy seems to have a great degree of inertia (Joskow and Rose, 1989 and Faure-Grimaud and Martimort, 2000). Regulatory policy seems, in fact, to react only to major political shocks rather than to changes in economic factors. The departure from the status quo may be, for this kind of policy, even more difficult than for others.

${ }^{24}$ As Romer and Rosenthal (1987, p.111) pointed out: "[...] ideology is a dimension on which are projected the myriad issue dimensions of politics. It is a remarkable fact that a single dimension, with considerable stability, characterizes voting in the U.S. congress. [...] voting in a manner consistent with ideological location may well be consistent with close attention to constituents interest".

${ }^{25}$ As Thomas Cusack (1997) points out, "Lower income groups and labor in general [i.e., the "left"] are seen as favoring a large and active state. This is a state heavily engaged in regulating the market and using public finance to equalize the outcomes of market operations."

${ }^{26}$ On the other hand, one could expect right-wing governments, which should be more "pro-business", to regulate entry more heavily in order to protect the interests of those firms which already are in the market.
} 
Yet, one legitimate question is whether the right-left dimension is a sufficient statistic for the parties'/governments' ideological position on particular issues, or whether information about the governments' programmatic position on these particular issues do a better job in explaining policy variation. In our case, we can use some interesting measures on issues such as regulation and welfare state limitation, and hence analyze how the right-left variable's significance level varies after inserting such measures as regressors. In a sense, this is a test of the explanatory power of the right-left synthetic measure.

\subsection{Private Interests}

The private interests theory of regulation stresses the role of competition among interest groups in shaping economic policy. If all parties are equally represented, the tougher this competition is, the more efficient the policy outcome should be. Generally, though, the industry has more intense and better organized interests than, for instance, consumers, who are also affected by regulatory reforms and whose interests are often opposite to those of the industry (more competition to foster lower prices, higher quality, and more product diversity). Consumers, in fact, face the typical free rider problem in group formation (Olson, 1965), hence their lobbying activity might be less effective than the lobbying by telecommunication firms that already operate in the market, which are few and whose interests are more aligned. Among firms, though, there can also be strong differences. Incumbents should be more interested in protecting their market from new entry, calling for a tougher entry regulation. On the contrary, potential entrants should lobby to lower entry barriers and to push forward the liberalization process.

In this paper, we will analyze this kind of mechanism, at least partially. Our expectation is that the higher the incumbents' market share, the more resources it should spend in order to slow down the liberalization process. These firms have in fact much to loose in a liberalized environment. On the other hand, when the industry profits are high, then the entrant firms' lobbying intensity should be higher, since the gain from lobbying - i.e., the possibility to enter a profitable market - is higher. ${ }^{27}$ Finally, from the consumers' side, we use the "active" population, i.e. the population between 15 and 64 years, as a good proxy for the consumers' interests. Relative to the entire population, adolescents and people in the labor force would mostly gain from a liberalization of the mobile industry. The reason is that liberalization should imply a more competitive environment with lower prices and these groups are the main potential users.

Hypothesis 5 Countries are more likely to liberalize when the incumbent's market share is low, the industry profits are high, and the proportion of "active" population is high.

\footnotetext{
${ }^{27}$ This is by no means a perfect measure for potential entrant's interests, since high profits are also in the interest of the incumbent firm. However, one can hope to capture the former if controlling for another measure of the incumbent's interests such as its market share.
} 


\subsection{Regulatory Institutional Environment}

The regulatory institutions in place are the result of a delegation process involving politicians and bureaucrats. As already mentioned, this relationship has been widely analyzed in the theoretical literature. Nevertheless there is little empirical evidence helping to evaluate this theories. The government writes contracts that should entail the "right" incentives for bureaucrats to operate efficiently. This analysis, however, is beyond the scope of this paper. We will assume that the institutions that result from these contracts shape economic policy decision. ${ }^{28}$

One problem in our specific case is that regulatory institutions in telecommunications have been partially reformed during the sample period, and sectorial authorities were created to handle the liberalization and privatization processes. In our approach, instead, we assume that regulatory institutions remained constant during the sample period, since the information contained in the OECD database does not follow their temporal evolution, but rather gives a picture of them around the end of the sample. Nevertheless, we think that it is useful to incorporate these variables in our study, in order to stimulate the discussion, but keeping in mind that a deeper and more careful analysis is needed.

There are essentially two main characteristics of a regulatory agency, which have been pointed out as particularly important to explain their ability to implement regulatory policy: their independence and their accountability. The argument about regulator's independence from the political power that appointed it is that such independence should help to ease the regulatory capture problem (Laffont and Tirole, 1993). First, a more independent regulator should face a less severe time inconsistency problem, because it is less concerned with electoral cycle considerations. Second, a more independent regulator should more likely purse the general interest, because it is less dependent on a captured government. The argument behind the idea to keep agencies more accountable is that this accountability should "counterbalance the natural inequality in the ability of different interest groups to influence regulatory practice, including the well-known tendency for consumer interests to be less well organized than those of producers" (Neven et al., 1993). If this is true, then one should expect to observe a more pronounced liberalization pattern in those countries where the agencies were more independent and more accountable.

Hypothesis 6 Countries are more likely to liberalize when their regulatory authority are more independent and more accountable.

\footnotetext{
${ }^{28}$ The theory of regulatory capture proposed by Laffont and Tirole (1993) stresses the role of the regulatory environment in shaping interest groups' ability to influence the regulatory policy. Regulatory institutions should then be designed in order to minimize the possibility of regulatory failure.
} 


\subsection{Demographic and Economic Controls}

We control for specific demographic and economic characteristics which are supposed to constitute a source of observable heterogeneity among countries, such as the population level (POP) and the income per capita (YPC). In fact, a correlation between higher income per capita and good government and lower need for regulation is likely to exists. ${ }^{29}$

In general, we make these controls to account for the demographic and economic conditions of the country, which may shape the economic policy decision (Besley and Case, 2000). Furthermore, one can think of these controls as accounting for the differences in the market conditions among states. For example, we expect that small countries - such as Luxembourg - do not have a competitive market structure because they constitute a natural monopoly since potential demand is very small. Finally, we also control for a time trend, which should capture the market evolution and the technological change. These have been important elements determining the development of the mobile telecommunications industry and its regulation.

\section{The Data}

Our data set, merged from different databases, constitutes an unique source of information for analyzing of the politics of regulation. On the one hand, it contains information about the regulatory process, the market structure, and the regulatory environment in OECD countries; while on the other hand it includes information on these countries' institutional and political environment.

The regulatory variables are taken from a database on international regulation recently published by the OECD (see Boylaud and Nicoletti, 2000, Gonec, Maher and Nicoletti, 2000, and Nicoletti, 2001). The database consists of primary data, provided mainly by means of ad hoc questionnaires and existing OECD publications. Furthermore, some indicators were estimated to facilitate the use of the detailed aggregated data and to allow comparisons between countries with different regulatory systems. The primary data consist of qualitative information (such as binary answers, multiple choice answers or answers providing more detailed information about regulatory provisions) as well as quantitative information (such as number of licenses, market shares and industry performances). Additionally there are general reports about the regulatory environment in and around 1998.

Figure 1 displays two indexes on the regulatory intensity in the fixed line and mobile telecommunications industries developed by Boylaud and Nicoletti (2000), which were calculated aggregating different information through a factor analysis and represent an average over the period

\footnotetext{
${ }^{29}$ See Djakanov et al. (2001). A reason for this could be that richer countries may deal better with market failures than poorer.
} 
1991-1997. ${ }^{30}$ So, for instance, the UK presents the lowest regulatory intensity in the wireline and the mobile telecommunications industries. On the other extreme, Turkey and Switzerland regulate the most.

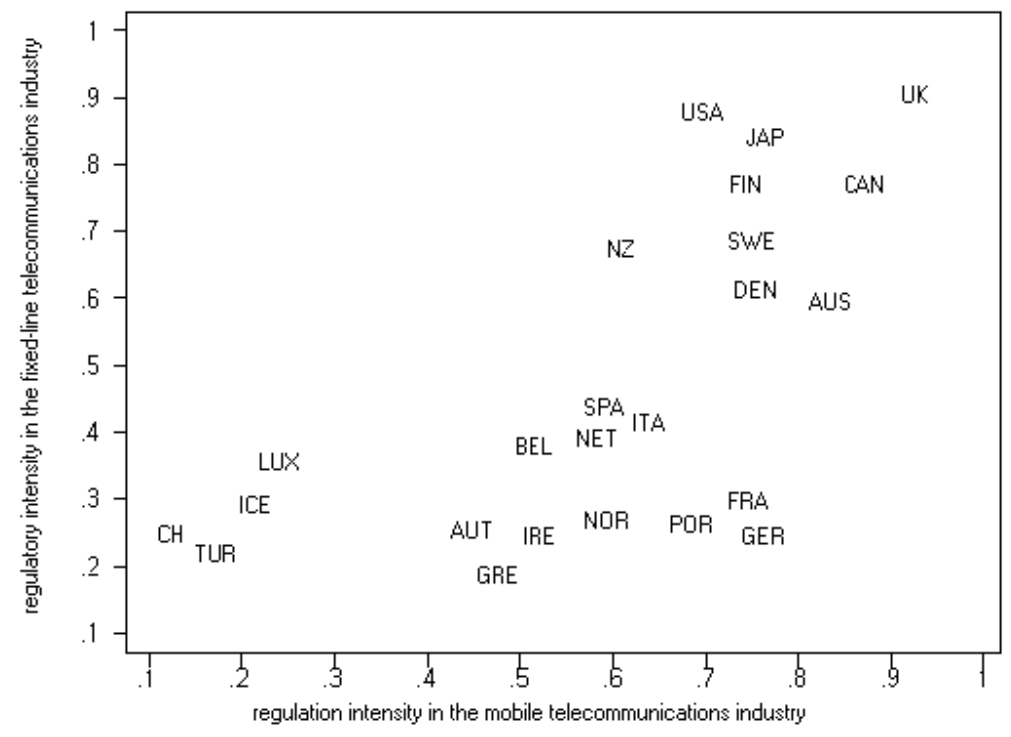

Figure 1: Regulatory intensity in the fixed-line and mobile telecommunications industries

The most interesting element, which emerges from the previous figure, is the high level of heterogeneity in the regulatory processes among OECD countries. Figure 2 plots the index on regulatory intensity in the mobile telecommunications industry and the degree of liberalization of the digital mobile telecommunications industry. ${ }^{31}$

Also in this case, we observe a great deal of heterogeneity among countries, with the UK on the top-right corner (competitive industry with low regulatory intensity) and Switzerland on the bottom-left corner (monopoly and high regulatory intensity).

Moreover, looking at Figure 3, which plots the time evolution of the cross-sectional average of the degree of liberalization between 1991 and 1997, we observe also variability in the time dimension, which suggests that the deregulation and liberalization of the telecommunications

\footnotetext{
${ }^{30} \mathrm{~T}$ he " 0 " means high regulatory intensity while " 1 " means low regulatory burdens. The regulatory index for the mobile industry aggregate information about the internationalization, the liberalization and market structure of the domestic mobile telecommunications market, while the regulatory index for the fixed telephony considers also the state ownership of the PTO. We are very grateful to Giuseppe Nicoletti for sharing his data.

${ }^{31}$ In the Figure the time average of the variable DIGIT LIB is represented for each country. This variable takes value 1 if the market is a monopoly, 2 if it is a duopoly, and 3 if the market is more competitive ( 3 or more firms).
} 


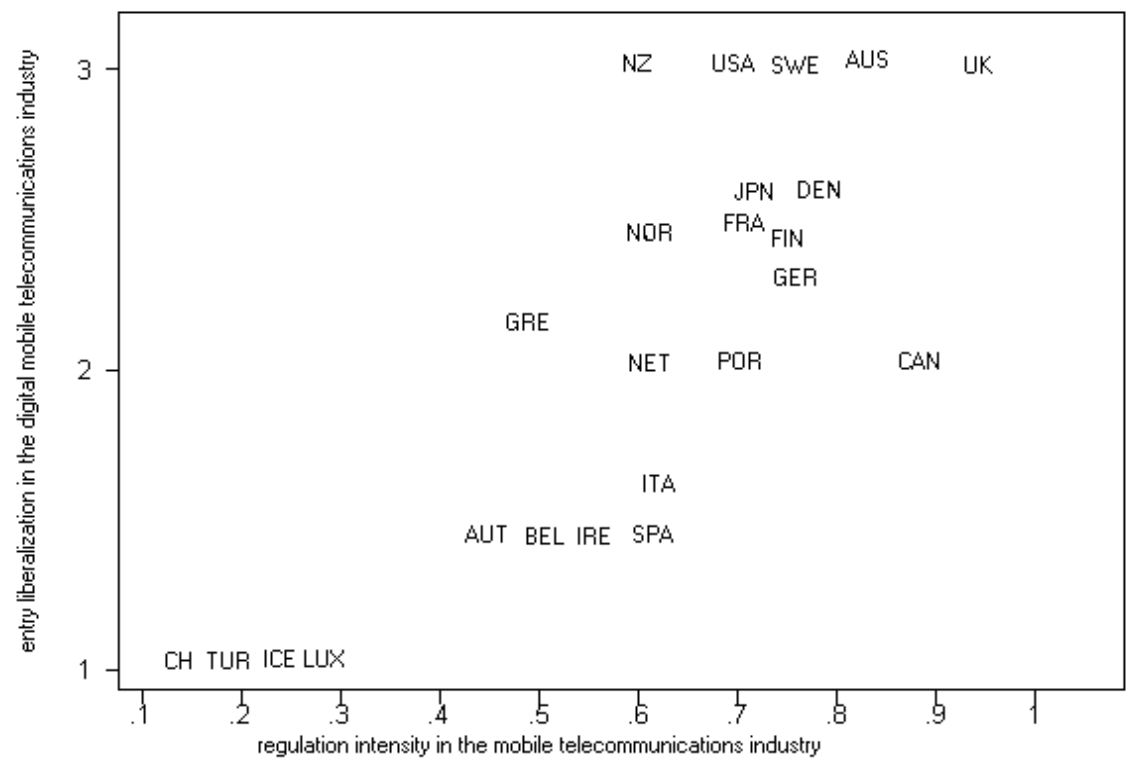

Figure 2: Degree of entry liberalization and regulatory intensity in the mobile telecommunciations industry.

industry was an on-going process during the sample period. Our aim is to explain both sources of variability in observed policy.

The second database that we use, which is our major source for the "political side" of our data, has been developed by the Institutions and Social Change's Unit of the Wissenschaftszentrum Berlin für Sozialforschung (WZB). The original data base was first built by the Manifesto Research Group of the European Consortium for Political Research (ECPR) and was later developed at the WZB in the so-called "Comparative Manifestos Project." In this data-set, various aspects of the party and governmental system are examined on the basis of quantitative content analyses of party manifestos and government declarations. The original collection includes 2,359 manifestos from 614 different parties in 461 national elections between 1945 and 1999 . This originates from 52 countries, including all OECD countries with the exception of Korea and 24 central and eastern European countries (see Budge et al., 2001). Furthermore, these original data have been extended to cover information about the elected governments during the sample period. This information, which has been derived from Woldendorp, Keman, and Budge (1998), has been subsequently extended and corrected at the WZB. ${ }^{32}$

Our data on political institutions is based on two sources. On the one hand, we use two

\footnotetext{
${ }^{32}$ We are particularly grateful to Andrea Volkens for kindly providing us the data.
} 


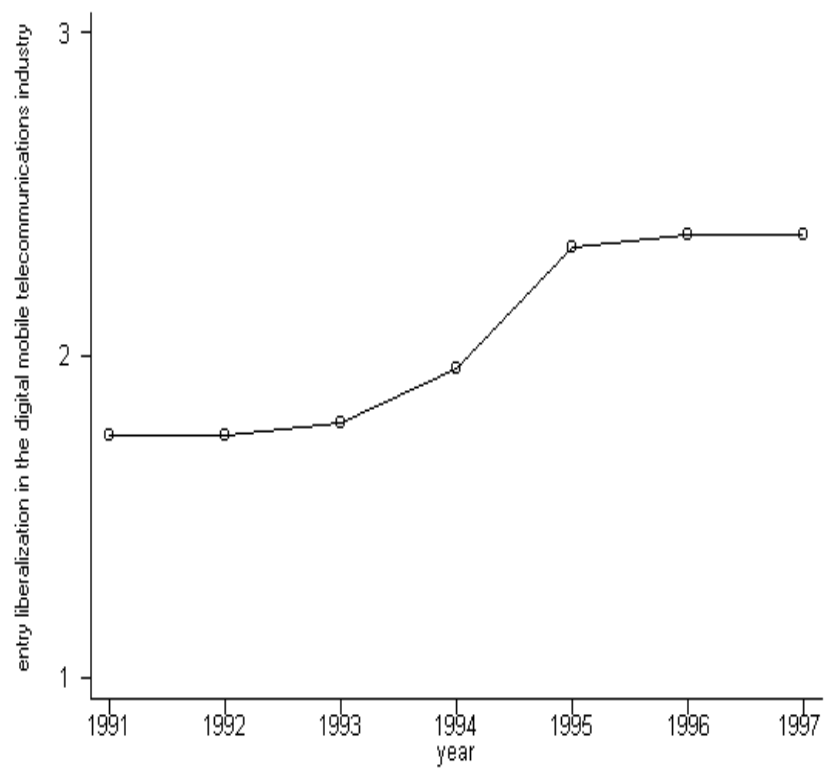

Figure 3: Time Evolution of Entry Liberalization in the Digital Mobile Telecommunications Industry

dummy variables developed by Persson and Tabellini (1999), which take value one for countries with majoritarian elections (MAJOR) and for countries with presidential regimes (PRES). ${ }^{33}$ On the other hand we use the two indexes (EXEC_PAR and FED_UNIT) developed by Arend Lijphart (1999) that we presented in the previous section. These indexes are a metric measure of the institutional details and, particularly, expressive of how majoritarian or consensual each country is along the two chosen policy dimensions. The distribution of countries along these two dimensions is graphically represented in Figure 4. For instance, the U.S. is consensual in the federal-unitary dimension ("[..] strong federalism and judicial review, a rigid constitution, an independent central bank, and a bicameral parliament albeit of only medium strength") and majoritarian in the executives-parties dimension ( " [...] dominant one party cabinets, a roughly two-and-a-third party system, plurality election and interest group pluralism"), whereas the U.K. is very majoritarian and Switzerland very consensual in both dimensions. ${ }^{34}$

Finally, from the OECD statistical compendium we collected information about the countries' demographic and economic conditions. Since the different data sets span different time periods and cover different countries we found a "minimum common denominator" in the merg-

\footnotetext{
${ }^{33}$ We thank Guido Tabellini for allowing us to use the data.

${ }^{34}$ The quotations from Lijphart (1999) p. 249.
} 


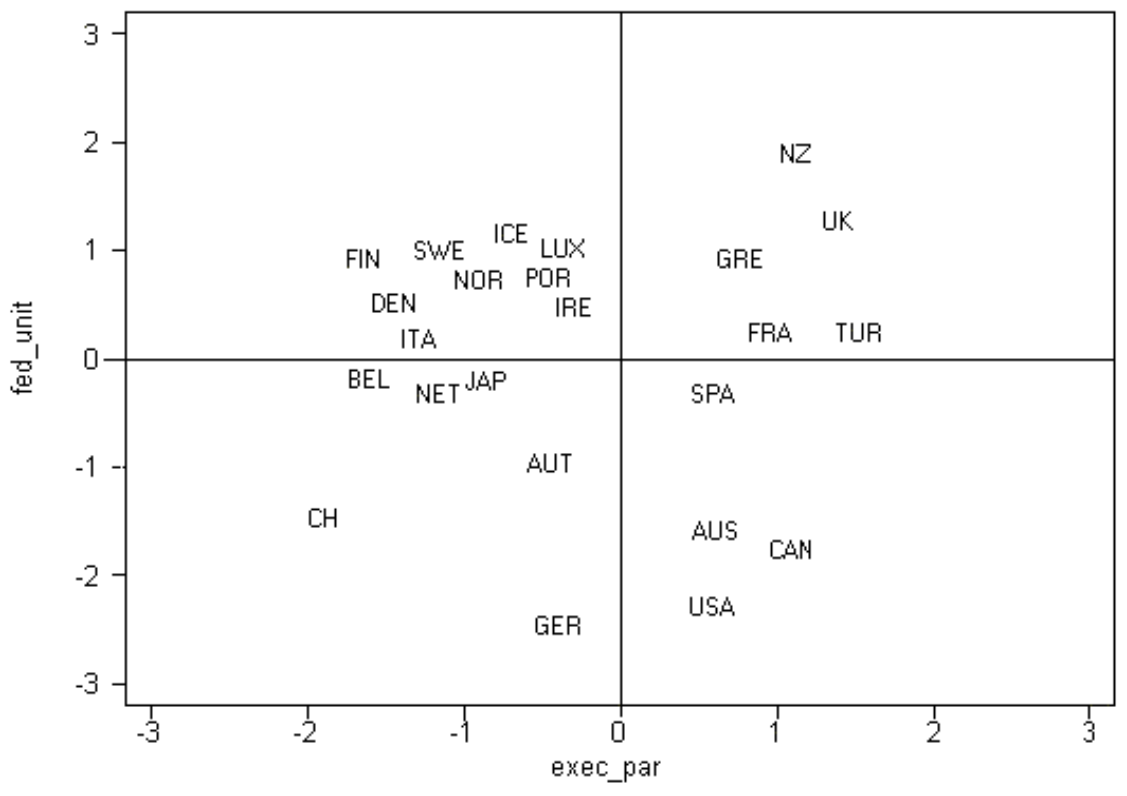

Figure 4: The Two-Dimensional Conceptual Map of Democracy

ing procedure. Our final data set covers 24 OECD countries in the time period 1991-1997. In Table 1a we briefly define the main variables and their sources, while Table $1 \mathrm{~b}$ presents the summary statistics for these variables.

Some first facts emerge. The different branches of the telecommunications industry have very different regulatory patterns. The wireline, which is an older industry with a long public monopoly history, had a higher degree of state control (FIXREG) than the mobile industry (MOBREG), which is instead a young, dynamic, and quickly developing industry. ${ }^{35}$ The more precise measure of entry liberalization in the digital mobile telecommunications industry (DIGITLIB) indicates that, in the sample period, cellular markets were on the average duopoly markets. On average, the incumbent firm had $63 \%$ market shares (SH_MD1). The state's ownership share in the incumbent telecommunications operator in the mobile industry (SH_INCMO) was on average 57\%. In the sample period and across countries the average mobile industry revenues per-year (REV_MOB) were equal to 10 thousand billion U.S. dollars.

In the sample, $25 \%$ of the countries had majoritarian elections (MAJ), but only $9 \%$ had a presidential regime (PRES). The other two institutional variables indicate that the average country was more consensual in the executive-party (EXEC_PAR) than in the federal-unitary (FED_UNIT) dimension.

\footnotetext{
${ }^{35}$ The two indexes take value 0 for high regulatory intensity and value 1 for low regulatory intensity.
} 
The governments represented in our final data set were mostly coalition governments (GOV_COAL in $57 \%$ of the observations) with 1.97 member parties on the average (COALSIZ) and an average center-right wing (RILE) orientation. ${ }^{36}$ The average government had the $55 \%$ of the seats in the legislature (PSEAT_G), and were opposed by more than 4 parties (OPP_PAR). The two variables related to the parties' programmatic position concerning specific policy questions - pro regulation (PRO_REG) and favorable to welfare state limitation (WELF_LIM) - represent, in percent value, how often a sentence relative to a particular policy area was mentioned in the party's program. ${ }^{37}$ So, for instance, pro-regulation statements constitute, on average, $1.77 \%$ of the government's program, whereas pro-welfare state limitation statements represent only $0.44 \%$ of the government's program.

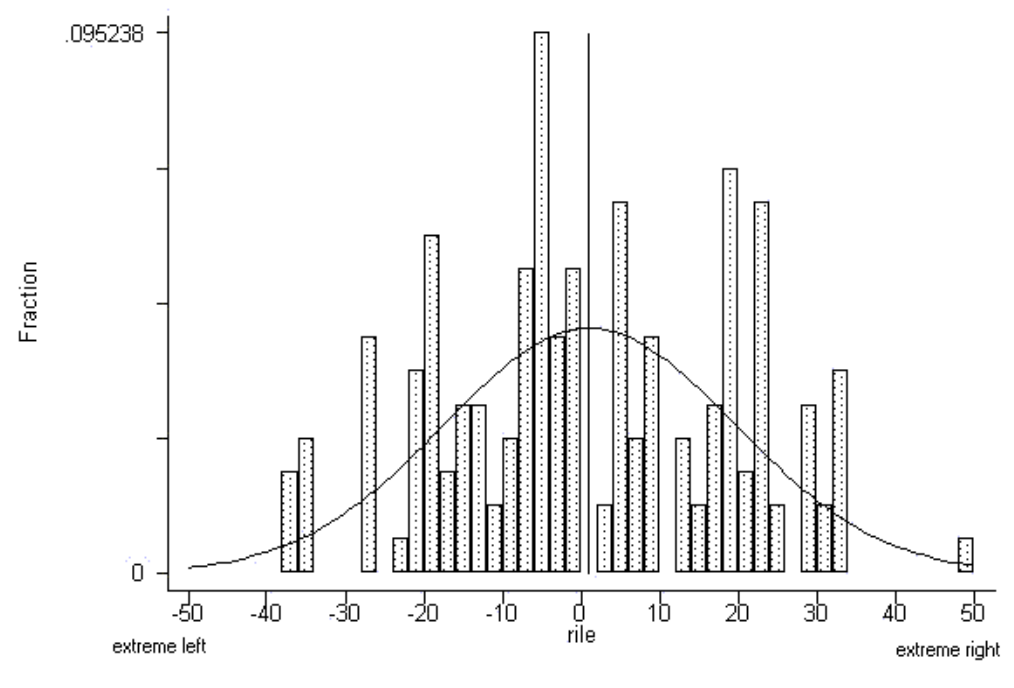

Figure 5: Government's Position on the Right-Left Dimension

The head of the regulatory authority had in $66 \%$ of the cases a definite term of office (TERM_DEF), was in $29 \%$ of the cases appointed by the prime minister (APP_GOV), in $17 \%$ of the cases by the president (APP_PRES) and in the rest of the cases by the sectorial minister. Finally, the regulatory authority was in $67 \%$ of the cases financed, at least partially,

\footnotetext{
${ }^{36}$ See Budge et al. (2001) for a precise description of how this variable was constructed. The variable takes values in the range -50 (extreme left) and +50 (extreme right). See Figure 5 for a graphical representation. For coalition governments, all the considered measures are a weighted average of the same measure for all parties in the government's coalition. The adopted weight is the percentage seats in parliament held by each party.

${ }^{37}$ See Budge et. al. (2001) for a more precise definition and motivation. The raw data include 56 categories grouped in 7 broader policy areas.
} 
through industry fees (FIN_IND), had a report duty (REP_YES) in $75 \%$ of the cases $(25 \%$ to the legislature and $50 \%$ to the minister), and in $70 \%$ of the case their decisions could not be overturned by any other political institution (OVER_NO).

\section{The Empirical Methodology}

The general form of the equation that we estimate is the following:

$$
\text { policy }_{i t}=\alpha+\beta_{t}+\gamma_{1} \mathbf{C}_{i t}+\gamma_{2} \mathbf{X}_{i t}+\epsilon_{i t}
$$

where $\alpha$ is a constant term, $\beta_{t}$ is a time trend, $\mathbf{C}_{i t}$ is a vector of demographic controls, and $\mathrm{X}_{i t}$ is a vector of exogenous political variables. We will use different sets of exogenous variables in order to observe how much of the cross-section and time-series variation in the observed policy can be accounted for by each of these sets.

\section{Cross-sectional regressions}

As a first step in our empirical study we analyze the cross-sectional variability in regulatory intensity. For this first set of regressions we can thus use the index for the mobile telephony developed by Boylaud and Nicoletti (2000), which is a richer and more informative measure of the regulatory environment. We perform a cross-sectional regression, where we collapse all variables towards their mean value (a bar over the variables means that we take their time average): ${ }^{38}$

$$
\overline{\text { policy }}_{i}=\alpha+\gamma_{1} \overline{\mathrm{C}}_{i}+\gamma_{2} \overline{\mathrm{X}}_{i}+\epsilon_{i}
$$

We perform two robustness tests: the Cook-Weisberg test for heteroskedasticity and the Ramsey RESET test for omitted variables. ${ }^{39}$ Although we have very few observation (24 countries in the sample), we will observe whether some first qualitative results emerge, which can later be compared to the findings obtained with the more correct panel methods. The advantage of this approach is that we concentrate on the policy's cross sectional variation only.

\section{Panel Regressions}

As we already acknowledged, our database allows us to use panel methods to account for unobserved heterogeneity. This approach should lead to more accurate estimates of the effects of political-economic variables on policy outcome. Unfortunately, the indicators developed by

\footnotetext{
${ }^{38}$ This is the so called between estimator, it is not particularly efficient, since it discards all the over-time information of the data.

${ }^{39}$ For a description see STATA manual vol. 3 p. 97.
} 
Boylaud and Nicoletti (2000) are averaged over the sample period and, therefore, do not present time variation and cannot be used in panel regressions. Hence, we use a second variable related to the degree of liberalization and of entry liberalization in the digital mobile telecommunications industry (DIGITLIB) as a dependent variable. This takes value 1 if the market is a monopoly, 2 if it is a duopoly, and 3 if the market is more competitive ( 3 or more firms). ${ }^{40}$ This ordered variable can be seen as the observable counterpart of a continuous latent variable, which can be thought of as the "intensity of entry liberalization", or as the utility derived by the policy maker by implementing one of the mentioned market structures.

One could estimate such a model as a linear regression model, denying the ordinal nature of the dependent variable, and in this way implicitly assuming that the intervals between adjacent categories are of equal length. This would imply a potential bias in the coefficients' estimates that can be very strong. The appropriate method to estimate a model with an ordinal dependent variable is the so called ordered probit model. ${ }^{41}$ Furthermore, because of the panel nature of our sample, we estimate the ordered probit model with country random effects, where it is assumed that the error term is constituted by two components, a country specific term $u_{i}$, and a white noise error term $\epsilon_{i t}$ :

$$
\begin{aligned}
& \text { policy }_{i t}^{*}=\alpha+\beta_{t}+\gamma_{1} \mathrm{C}_{i t}+\gamma_{2} \mathrm{X}_{i t}+u_{i}+\epsilon_{i t} \text {, } \\
& \text { policy }_{i t}=\left\{\begin{array}{ll}
1 & \tau_{0} \leq \text { policy }_{i t}^{*}<\tau_{1} \\
2 \text { if } \quad \tau_{1} \leq \text { policy } \\
3 & \tau_{2} \leq \tau_{2} \\
3
\end{array} .\right.
\end{aligned}
$$

Where policy $_{i t}^{*}$ is the latent variable, policy $y_{i t}$ is the observed categorical variable, and the $\tau^{\prime} s$ are the so called thresholds, which determine the length of each category and which will also be estimated. ${ }^{42}$

For the panel specifications, we adopt as a measure of fit the Mc Fadden's pseudo R-squared, which is defined as follows:

$$
R_{M F}^{2}=1-\frac{\ln \widehat{L}\left(M_{\beta}\right)}{\ln \widehat{L}\left(M_{\alpha}\right)}
$$

\footnotetext{
${ }^{40}$ Unfortunately, the information about the number of firms is not available in the database. The right censoring problem could therefore not be overcomed.

${ }^{41}$ The ordered probit model assumes that the error term is normally distributed. See Long (1997) for a very clear presentation of ordinal regression models. See also Maddala (1987) for further discussion.

${ }^{42}$ We used LIMDEP to estimate the ordered probit model with random effects. The identification assumption in this case is that $\tau_{1}=0$ and the model is estimated with a constant. See Limdep Users' Manual (1998).
} 
where $\ln \widehat{L}\left(M_{\beta}\right)$ is the log-likelihood function for the model with regressors, while $\ln \widehat{L}\left(M_{\alpha}\right)$ is the log-likelihood function for the model with just the intercept.

\section{Empirical Results}

In this Section, we summarize our results. The main aim of this study is to produce robust stylized facts about the political economy of the regulatory process. We intentionally adopt a reduced form approach, although we recognize that it has potential pitfalls, especially concerning the interpretation of the coefficients' estimates. Nevertheless, we are confident that our analysis can contribute to the debate on the politics of regulation, because the empirical evidence is still very scarce.

\subsection{Cross-sectional Regressions}

Table 2 is our starting point. It reports the results of the cross-sectional regressions, where the dependent variable is the regulation intensity index in the mobile telecommunications industry (MOBREG) developed by Boylaud and Nicoletti (2000). Following our presentation in the previous section, we regress different sets of dependent variables separately, in order to understand how much each of those sets contributes to an explanation of the cross-sectional variability in the regulatory policy. Since the number of observations is quite small, we choose to adopt parsimonious specifications.

The first set of political variables that we consider relates to the country's political institutions. In this case, we only use the institutional dummies taken from Persson and Tabellini (1999). These measures of political institutions are highly significant and have the expected sign. In particular, the degree of deregulation is higher in countries with a majoritarian election rule (MAJ), while the presidential regime type implies a tougher regulatory policy (PRES). ${ }^{43}$ Among the control variables, only the population is significant. This specification has a very high explanatory power $\left(A d j . R^{2}=0.5248\right)$, meaning that more than $50 \%$ of the variation in regulatory intensity among countries can be explained by these simple measures of their political constitution. Both the null hypotheses of homoskedasticity and no omitted variables are not rejected, which gives us confidence in our estimates.

\footnotetext{
${ }^{43}$ We also run the same regression using the metric measures of institutions. Both measures are significant and, as expected, more majoritarian countries in both the executive-parties (EXEC_PAR) and federal-unitary (FED_UNIT) dimensions were better able to implement the liberalization process in the mobile telecommunications industry. We then run the model with the four variables together, the results remain practically unchanged and the fit of the regression increases significantly $\left(A d j . R^{2}=0.6578\right)$. In this latter case, however, the heteroskedasticity test fails. These results can be obtained from the author upon request.
} 
The second set of political variables that we use is also related to institutional details, and particularly to the government type and viability. We contrast one-party (GOV1P) to coalition governments (GOVCOAL), and we further control for the cohesiveness of the coalition governments, as expressed by the number of parties in the coalition (COALSIZ), for the government's support in the legislature (PSEAT_GO), and for opposition's fractionalization (OPP_PART).$^{44}$ In this case, the political variables are almost not significant. The only significant term is the percentage seats in the legislature held by the government parties, which is negative. The Adjusted R-squared was much lower than in the previous specification and the F-test failed, meaning that this specification was bad.

We then test the role of the government's ideological position, using three different measures. First, we use the synthetic indicator for the government's right-left position (RILE). This variable, which was created by Laver and Budge (1992) and tested several times by political scientists, is a synthetic measure for the overall political position of the considered party. ${ }^{45}$ All other things being equal, the government's position in the right-left dimension does not play a significant role in explaining regulatory intensity. ${ }^{46}$ To better understand how strong the ideological position concerning some specific issues is transformed in effective policy - once the parties came to power - we use two further variables, which are related to the government's attitude towards regulation (PRO_REG) and towards the welfare state's limitation (WELF_LIM). Both variables have the expected sign, but only the pro-welfare limitations position is significant at the $10 \%$ level: Governments formed by parties which were programmatically in favor of welfare state's limitations liberalized more. Sign and significance of the demographic controls are similar to the previous specifications. Also this last specification has a quite high explanatory power (Adj. $R^{2}=0.5058$ ), even though the regression seems to be badly specified since the F-test fails. Both the omoskedasticity and the Ramsey tests accept the null hypotheses.

We then regress our dependent variable on a set of variables, which should capture the private interests theory's arguments. While, on the one hand, we proxy the incumbent firms' interest by using their market share (SH_MD1), on the other hand we proxy potential entrants' interests by using the $\log$ of industry revenues $\left(\log \left(\mathbf{R E V} \_\mathbf{M O B}\right)\right)$. Finally, we use the population between 15 and 64 years (ACTPOP) to proxy for the consumers' interests. Only the proxy for the incumbent's interests results significant at the $1 \%$ level: a strong incumbent achieved a less liberalized environment. The variable that proxies for consumers' interests - i.e., the

\footnotetext{
${ }^{44}$ For identification, we suppress the GOV $1 P$ dummy since we estimate the model with a constant.

${ }^{45}$ For coalition governments, the considered measure is a weighted average of the same measure for all parties in the government's coalition. The adopted weight is the percentage seats in parliament held by each party.

${ }^{46}$ Note that this stays true also if we regress the regualtory intensity on the controls and RILE alone. However, it should also be mentioned that the use of such a measure in the cross sectional regression may be problematic, since we average the position of different governments along the time dimension.
} 
"active" population - has the expected positive sign, but it is not significant. The variable that proxies for the potential entrants' interests is not significant as well, but it presented the negative sign. ${ }^{47}$ The fact that both these variables are not significant is not unexpected. For consumers, as well as for potential entrants, it is much more difficult than for an incumbent firm to organize their interests because of the well known free riding problem in lobby formation. Furthermore, potential entrants might have found it more difficult to lobby effectively, since they were endowed with less resources than the incumbent firm. This specification performs extremely well, explaining more than $70 \%\left(A d j . R^{2}=0.7306\right)$ of the variability in regulatory intensity. The proposed specification tests accept both the null hypotheses.

Finally, we analyze the role of regulatory institutions. We proxy regulator's independence by a dummy equal to one if the regulator's decision could not be overturned by any other political institutions (OVER_NO), and regulator's accountability by a dummy equal to one if the agency must report either to the parliament or to the sectorial minister (REP_YES). Surprisingly, we find a negative and statistically significant (5\% significance level) relationship between our measure of regulator's independence and the intensity of regulation: a more independent regulator adopted a more restrictive regulatory policy. In contrast, regulator's accountability has a positive, though not significant, impact on regulatory intensity. This specification performs much worse than the previous ones $\left(A d j . R^{2}=0.3221\right)$ but, as we pointed out, this can be due to our measures of regulatory institutions rather than to theoretical reasons. In this case, in fact, both the omitted variable and the omoskedasticity tests fail.

\subsection{Panel Regressions}

Next, we perform panel regressions, which should enable us to make more precise and accurate predictions, since they allow us to control for unobserved heterogeneity across observations. In this case, however, we cannot use the synthetic index developed by Boylaud and Nicoletti (2001) as the dependent variable, because it does not entail the temporal dimension. As we already mentioned, we use in this case DIGITLIB as the dependent variable, which is an ordered variable that describes the degree of market liberalization. A precise comparison with the previous results is not possible since the dependent variable is different. However, we can still compare whether the significance and the direction of the coefficients' estimates are consistent with the previous estimations. ${ }^{48}$ Moreover, we must keep in mind that in this case we also capture the additional variation in the dependent variable along the time dimension. For this

\footnotetext{
${ }^{47}$ Since high revenues are also in the interest of incumbent firms, one can think that the coefficient's estimate is not significant because the opposite actions of incumbents and entrants counterbalanced.

${ }^{48}$ The two variables - MOBREG and DIGITLIB - are, in fact, strongly positive correlated (the correaltion coefficient is 0.7024$)$.
} 
reason, we also introduce a time index (TIME_IND) to account for temporal changes in the market. ${ }^{49}$ Since the ordered regression model is non linear in the outcome probabilities, the interpretation of coefficients' size is not straightforward. Hence, we concentrate our analysis on the sign and significance of coefficients. ${ }^{50}$

Table 3 reports the results for the specifications in which we use the political institutions as the explanatory variables. Among the control variables, only the time trend appear to have a significant and positive effect, which means that there was a general tendency towards liberalization during the 1990's. ${ }^{51}$ The population has a positive but less significant impact on cellular markets' liberalization, while the income pro capita has no significant impact on the liberalization process. The positive sign of the population coefficient was expected, since in larger countries the potential users of mobile services are more, therefore a more competitive market structure is sustainable.

When we turn to the variables related to political institutions, we observe that some of them are highly significant. This broadly confirms the previously obtained results, yet some differences emerge. The two institutional dummies have the expected sign: countries with majoritarian elections liberalized more, whereas countries with presidential regimes liberalized less. However, we observe that the presidential dummy is never significant. In the second specification, when we use the two institutional indexes alone, both of them are highly significant and have the expected negative sign: the need for consensus in both institutional dimensions made policy change more difficult. The fit of the regression, though, decreases if compared to the first specification. Finally, we propose a third specification where all the institutional measures are simultaneously used and only two of them stay significant. The majoritarian dummy and the index of consensus in the federal-unitary dimension are still highly significant and have the expected signs. Both effects reinforce if compared to the previous specifications. The presidential dummy and the executive-party dimension's index have instead the expected signs, but are not significant. In all specifications, the standard deviation of the random effects (SIGMA) is highly significant, which indicates that this econometric approach is appropriate, since unobserved heterogeneity

\footnotetext{
${ }^{49}$ We do not estimate the model with time fixed effects because the dependent variable presents little variation in the time dimension. The use of years dummies lead in fact to problems in the convergence of the estimates.

${ }^{50}$ In order to make clear predictions on the coefficients' size, one should considered the fully standardized coefficients. In this case the effect of the independent variables on the latent dependent variable can be indicate in its original unit of measure. Predictions will then be in terms of standard deviation increases, which are anyway difficult to give a economic sense.

${ }^{51}$ This was expected. Starting from the 1980's, an "era of deregulation" has started in most of the industrialized countries, following the idea that state intervention cannot enhance market efficiency. Since then public utilities, and telecommunications in particular, have been widely deregulated and liberalized. Moreover, as we mentioned, the time trend should also capture the positive effect of technological change, which might have made possible the implementation of a more competitive market structure.
} 
among countries matters. Concerning the measure of fit, the first specification is the best and explain almost $43 \%$ of the observed cross-sectional and temporal variation in the observed policy. Yet, a direct comparison with the cross-sectional regressions is difficult because the dependent variables differ. Nevertheless, we can point out that political institutions explained much of the cross-sectional variation in the liberalization process, but they seem to be less able to explain its temporal variability. ${ }^{52}$

Table 4 displays the results of the specifications where we use the government's type and its viability as the independent variables. Differently to the cross-sectional regressions, we find evidence here that coalition governments have a strong and significant negative impact on the degree of entry liberalization. Moreover, when we control for the government's support in the parliament and for the number of opposition parties, also the size of the coalition has a positive impact on the industry's liberalization. If, on the one hand, this result seems to support the idea that veto players may impede policy reform because coalition governments liberalized less, on the other hand, it is less clear why larger coalitions should have been able to liberalize more. ${ }^{53}$ The differences observed between cross-sectional and panel regressions might suggest that the government's type is more important for explaining the variability along the time dimension, i.e. the speed of the liberalization process, than the cross-sectional differences in the degree of entry regulation. Again, the random effects' standard deviation is highly significant, supporting our empirical approach. Both specifications show that the government's type could account for about $40 \%$ of the variability in the deregulation of entry.

Table 5 reports the results for the regressions of the degree of liberalization on ideological variables. First, we use the simple right-left position as a regressor. It is positive and significant at the $1 \%$ level, which means that, during the sample period, right-wing governments tended to liberalize more, as expected. We then use the two variables related to the more specific positions pro-regulation and pro-welfare state limitation, which are also significant at the $1 \%$ significant level. As expected, if the government announced to be pro-regulation it liberalized less, whereas if it announced to be pro-welfare-state-limitations it liberalized more. When we use the three measures simultaneously, however, only the programmatic position pro-regulation is significant and presents the expected negative sign. Looking at the pseudo R-squared, we observe that the second specification is the one which better performs, explaining almost $46 \%$ of the variability. ${ }^{54}$

\footnotetext{
${ }^{52}$ Also, we performed a likelihood ratio test between specifications in order to test whether the model of specification 1 and of specification 2 are nested in the model of specification 3 . We reject the null hypothesis that the constraints imposed to the second specification are true at the $1 \%$ significance level, while we accepted the null in the case of the first specification.

${ }^{53}$ Actually, Keefer (2001) proves that the favor to special interests can decrease in the number of veto players, if governments are formed by veto players from the group of veto players who are most harmed by favors to special interests. This could be a possible explanation for our finding.

${ }^{54}$ Again we perform the likelihood test in which we pair-wise compare the richest specification to the other two
} 
We then turn to the private interests theory of regulation. Table 6 displays the results for three different specifications. Because of the lack of information on market shares and industry's revenues, we must discard some observations. The first is a parsimonious specification, in which we insert one variable for each of the interests in place: the incumbent, the potential entrants, and the consumers. The results reflect our expectations, at least partially. First, the degree of entry liberalization is significantly lower when the incumbent's market share is larger. The interpretation is that the incentive to lobby and the lobbying effectiveness should increase with the incumbent's strength in the market, since its benefits from a concentrated industry structure are higher when its market share is bigger. The coefficient's estimate of the proxy for potential entrants' interests (industry revenues) is negative, but it is significant only in the first specification, while the coefficient's estimate of the proxy for consumers interests (active population) have the expected positive sign, but is not significant in any specification. Also this result was somehow expected. As we already acknowledged, both the potential entrants and the consumers face the typical free-rider problem in the creation of a lobby group, which can prevent them to effectively lobby the regulator. The measure of fit of this specification is comparable to the pseudo R-squared of the previous regressions. About $40 \%$ of policy variability is explained by our regressors.

In the second specification, we insert a dummy equal to one if the regulatory agency is, at least partially, financed through industry fees. The coefficient's estimate for the incumbent's market share stay negative and significant. Also the new variable's coefficient is negative and highly significant. The interpretation is that a regulator that is financed by the industry may be more easily captured. Finally, we also controlled for the state's ownership share in the incumbent firm. ${ }^{55}$ Also in this specification the estimated coefficient for the measure of the incumbent's private interests is negative and highly significant. Although these results seem to strongly support the private interest theory, one should take them cautiously. This is because to consider market structure's variables as exogenous may generate biased estimates, since the regulatory policy influences market structure. Therefore a two way causality between determinants and effects of regulation may exists, which should be accounted for (Duso, 2001 and Duso and Röller, 2001).

Finally, we analyze the role of regulatory institutions. Also in this case we estimate three different specifications. In Table 7 we report our findings. From the first specification it emerges that our measures of the regulator's accountability has a positive, large, and very significant (1\% level) impact on entry liberalization, while the measure for the regulator's independence is

specifications. The first specification is nested in the third, while this is not the case for the second specification.

${ }^{55} \mathrm{It}$ is worthwhile to mention that this variable can be endogenous. In fact, the telecommunications incumbent operator was privatized in the same period during which the industry was liberalized. Both processes have to be considered as part of the regulatory reform undertaken in the industry (OECD, 2000). 
not significant. ${ }^{56}$ When we turn to the second specification, in which we insert two dummies to control for the regulator's appointment method (equal to one if the regulator was appointed by the government or by the president respectively) we observe that these are positive and statistically very significant. While the result is difficult to interpret, it suggests that more precise measures of the regulator's independence should be developed. The regulator's appointment method, in fact, plays a crucial role in determining its independence degree. Finally, we control for a measure of the regulator's term of office. We use a dummy equal to one if the term of office is definite, which should also be a measure of regulator's independence. With a guaranteed term of office, in fact, the regulator can exercise its mandate without being subject to the possibility of being replaced by politicians responding to different interests. Interestingly, controlling for this variable increases the significance of all other measures. Moreover, both the new measure and the previously used independence's measure $\left(\mathbf{O V E R} \_\mathbf{N O}\right)$ are highly significant and negative: a more independent regulator liberalized less. In all specifications, the pseudo R-squared is slightly higher than in the previous models, which suggests that the role of regulatory institutions is crucial to understand the regulatory process.

How can we compare the obtained results? The first comparison can be done looking at the goodness of fit of the proposed models. We partially did it in the previous discussion. Differently than in the cross-sectional estimations, we do not observe marked differences in the pseudo R-squared among specifications. The best specifications, according to this measure of fit, are those related to political and regulatory institutions, which explain between $40 \%$ and $45 \%$ of the variability in the entry policy.

In order to perform a sort of specification test, we also estimate some mixed specifications, in which we insert the different sets of variables simultaneously, but using only those variables that have been found significant in the previous estimations. Table 8 displays our findings. In the first specification we use only political variables: the institutional measures, the government's type, and its ideological position are considered. The previously observed stylized facts stay true also in this richer specification at high significance levels. We then simultaneously use the variables related to the political and regulatory institutions. Qualitatively and quantitatively the results remain also in this case unchanged and parallel the findings previously observed. Also using political institutions and private interests variables together (specification 3), or regulatory institutions and private interest variables (specification 4) together, or all variables together (specification 5) does not affect the flavor of our results, even though some differences in the significance levels of the used variables can be observed. ${ }^{57}$ Also in this case, we can stress

\footnotetext{
${ }^{56}$ We divide the REP_YES dummy in two further dummies: REP_LEG=1 if the report duty is towards the legislative, and REP_MIN=1 if the report duty is towards the sectorial minister.

${ }^{57}$ In particular, using political institutions and private interest variables simultaneously reduce the significance of our coefficients' estimates.
} 
that all sets of variables could help in disentangling policy variation.

\section{Concluding Remarks}

In this paper we empirically analyzed the political economy of the regulatory reform in the mobile telecommunications industry in 24 OECD countries during the 1990's. After giving an overview of the literature on the political economy of economic policy, we identified some theoretical predictions that we would expect to be observed in the data. This exercise had the aim of producing some robust stylized facts, which could help in the developing of new theoretical tools for the analysis of the political economy of regulation. An unique data set, obtained by merging different data sources, was developed, which allows for a time-series and cross-sectional analysis of the politics of the regulatory reform.

Different strands of the literature were surveyed, in order to obtain the most general view about the economic and political factors that shape economic policy. First, we asked what is the role of the state's political constitution - as expressed by the electoral rule, the regime type, and by two other synthetic measures of political institutions - in shaping the regulatory policy. Second, we asked what is the role of the governments' types, concentrating on the political viability that the different governments' types may have. Third, we analyzed the role of ideology and partisanship: a synthetic measure of the government's overall right-left position, and two other measures relative to specific programmatic positions were considered. Fourth, the effects of the industry's private interests were analyzed in the spirit of the Chicago School's approach to regulation. And finally, we considered some characteristics of the regulatory authorities, in order to analyze whether the regulatory institutions in place also shape the liberalization process.

Concerning the empirical specifications, we adopted different econometric techniques. As a starting point we performed some cross-sectional regressions and then moved to a more accurate analysis of the liberalization process using panel techniques. Some of the observed results found a motivation in the existing theory, but we stressed the strong need for more specific and microfounded theoretical models, able to cover the different approaches taken in this paper.

Some robust findings emerged out of our study. The first robust result was that political institutions also matter for the regulatory policy. In particular, countries with majoritarian elections liberalized substantially more the mobile telecommunications industry. The regime type seems instead to have had a less pronounced impact, even though, we observed a week negative relationship between liberalization and presidential regimes. Finally, the more accurate metric indexes of institutions showed that countries that were more majoritarian on the federalunitary dimension and, to a smaller extent, on the executive-party dimension have been better able to produce policy change in the form of entry liberalization of the mobile telecommunications 
market.

The government's type was also observed to be a relatively important factor that explained the liberalization variability among countries. In particular, our findings suggested that coalition governments slowed down the liberalization process, but, surprisingly, that this effect was declining the larger the coalition. The government's ideological position played only a minor role. This can be partially explained by the fact that, during the sample period, there was a generalized tendency in the entire political spectrum to consider entry deregulation as a "good" policy. Our suggestion is that ideology might have been important in explaining how fast the process was developed. The overall right-left position was not particularly significant, however we found some weak evidence that right wing governments were, as expected, more favorable to deregulation and liberalization. More interestingly, the programmatically announced position in favor of the state intervention in the economy was at least partially fulfilled in the realized policy: governments that announced to be pro-regulation liberalized less.

We found strong evidence that the incumbent's private interests were reflected in the liberalization patterns. Strong incumbents were able to limit the extent of entry liberalization, protecting the rent stemming from a highly concentrated industry. However, we stressed that it would be necessary to directly assess the simultaneity between market and policy, when testing the private interest theory of regulation, in order to avoid possible endogeneity problems.

Finally, regulatory institutions played a crucial role. Regulator's accountability, in particular, was a factor that helped the liberalization of entry in the mobile telecommunications industry. While the results about the role of regulator's independence were not clear cut, even though it appeared that the regulator's independence also shaped the policy decision, yet more in the direction of a less liberalized environment.

In this study, we gave a first glance at the data and found some results, which cannot be fully explained by the existing theory on the political economy of regulation. We acknowledged the need for some microfounded models, which can more clearly predict why and how political and regulatory institutions - as well as the influence of pressure groups - matter for regulatory policy. Furthermore, it would also be interesting to have some model on how the forces which shape the regulatory process interact among each other, even though about this point we still do not have any empirical evidence. While the development of such models is a challenging theoretical issue per se, we also think that it could be very helpful for empirical analysis, since it would help in the development of clear cut empirical tests.

This work reached the, perhaps obvious, conclusion that politics also matter for this kind of industrial policy. One promising extension of our approach is the development of a political model of industrial policy, where policy determination and policy incidence are simultaneously considered (see Duso and Röller, 2001). This seems to us to be an challenging research field 
both for empirical and theoretical industrial economists.

\section{R eferences}

A lesina, A lberto, "Macro-economic policy in a two-party system as a repeated game," The Quarterly J ournal of E conomics, 1987, 102, 651-78.

_ and Allan Drazen, "Why Are Stabilizations Delayed?," American Economic Review, 1991, 81, 1170-88.

_ and Howard R osenthal, Partisan P olitics, Divided G overnment and the E conomy, Cambridge: Cambridge University Press.

A usten-Smith, David, "R edistributing I ncome under Proportional Representation," J ournal of Political Economy, 2000, 108, 1235-1269.

Baron, David, "Regulation and Legislative Choice," RAND J ournal of Economics, 1988, 19, 467-477.

B ecker, Gary S., "A T heory of Competition A mong P ressure Groups," The Quarterly J ournal of E conomics, 1983, 98, 371-400.

Bergman, Lars, Chris Doyle, J ordi Gual, Lars Hultkrantz, Damien Neven, LarsHendrik Röller, and Leonard Waverman, Europe's Network Industries: Conłicting Priorities. Monitoring E uropean Deregulation. 1-Telecommunications, London: CEPR, 1998.

Bernheim, Douglas B. and M ichael D. W hinston, "M enu A uctions, R esource Allocation, and E conomic Infuence," The Quarterly J ournal of E conomics, 1986, 101, 1-31.

Besley, Timothy and Anne Case, "Unnatural Experiments? Estimating the Incidence of Endogenous Policies," The Economic J ournal, 2000, 110, F672-F 694.

B oylaud, Olivier and Giuseppe Nicoletti, "R egulation Market Structure and Performance in Telecommunications," Economics Department Working Paper, No. 237, OECD, Paris 2000.

Buchanan, J ames M. and Gordon Tullok, The Calculus of Consensus, Ann A rbour: University of Michigan Press, 1962. 
Budge, Ian, Hans-Dieter Klingelman, Andrea Volkens, Judith Bara, and Eric Tanderbaum, Mapping Policy P references. Estimates for Parties, Electors and Governments 1945-1998, Oxford: Oxford University Press, 2001.

Chang, Ha-J oon, "The Economics and Politics of Regulation," Cambridge J ournal of Economics, 1997, 21, 703-728.

Cusack, Thomas, "Partisan Politics and Public F inance: Changes in Public Spending in the Industrialized Democracies, 1955-1989," Public Choice, 1997, 91, 375-95.

De-Soto, Hernando, The Other Path, New York: Harper and Row, 1990.

Djankov, Simeon, Rafael La Porta, F lorencio Lopez de Silanes, and Andrei Shleiler, "The Regulation of Entry," Quarterly J ournal of Economics, 117.

Duso, Tomaso, "Lobbying and Regulation in a Political Economy: Evidence from the U.S. Cellular Industry," WZB Discussion Paper FS-IV 01-03, W issenschaftszentrum B erlin für Sozialforschung 2001.

_ and Lars-H endrik R öller, "Toward a P olitical E conomy of Industrial Organization: Empirical Regularities from Deregulation," W ZB Discussion Paper F S-IV 01-17, Wissen schaftszentrum B erlin für Sozialforschung 2001.

Estache, A ntonio and David M artimort, "Transaction Costs, Politics, Regulatory Institutions, and Regulatory Outcomes," EDI Regulatory Reform Discussion Paper, The World Bank, Washington D.C.

Faure-Grimaud, A ntonie and David M artimort, "Regulatory Inertia," mimeo, London and Montreal 2000.

Fiorina, M orris P., "Legislative Choice of Regulatory Forms: Legal Process or Administrative Process?," Public Choice, 1982, 39, 33-66.

Gawande, Kishore and U sree Bandyopadhyay, "Is P rotection for Sale? Evidence on the Grossman-Helpman Theory of Endogenous Protection," Review of Economics and Statistics, 2000, 82, 139-152.

Goldberg, Penelopi and G iovanni Maggi, "Protection for Sale: An Empirical Investigation," American Economic Review, 1999, 89, 1135-1154.

Gonec, R auf, M aria M aher, and G iuseppe N icoletti, "The Implementation and Exects of Regulatory Reform: Past Experience and Current Issues," E conomics Department Working Paper, No. 251, OECD, Paris 2000. 
— and _ _ Special Interest Politics, Cambridge MA: MIT Press, 2001.

Gruber, Harald and Frank Verboven, "T he Evolution of Markets under Entry and Standards Regulation - The Case of Mobile Telecommunications," International J ournal of Industrial Organization, 2001, 19, 1189-1212.

Hibbs, Douglas A., The American Political Economy, Cambridge, MA: Harvard University Press.

— The Political Economy of Industrial Democracy, Cambridge, MA: Harvard University Press.

Irwin, Douglas A. and R andal S. Kroszner, "Interests, Institutions, and Ideology in Securing Policy change: The Republican Conversion to Trade Liberalization after SmoothHawley," J ournal of Law and Economics, 1999, 42, 643-673.

J oskow, Paul and Nancy Rose, "The Exects of Economic Regulation," in R. Schmalansee and R.D. Willig, eds., Handbook of Industrial Organization.

Kalt, J oseph P. and Mark A. Zupan, "Capture and Ideology in the Economic Theory of Politics," A merican Economic Review, 1984, 74, 302-22.

Keefer, P hilip, "W hen Do Special Interests R un Rampant? Disentangling the Role of Elections, Incomplete Information, and Checks and Balances in Banking Crisis," Technical Report, Development Research Group, World Bank 2001.

K roszner, Randal S. and Phil Strahan, "What Drives Deregulation? Economics and Politics of the Relaxation of B ank Branching Restrictions," Quarterly J ournal of Economics, 1999, 114, 1437-1467.

Laxont, J ean-J acques, "Industrial Policy and Politics," International J ournal of Industrial Organization, 1996, 14, 1-27.

_ I Incentives and Political E conomy: 1997 Clarendon Lectures, Oxford: Oxford University Press, 1999.

— and David M artimort, "Separation of R egulators against Collusive Behavior," RAND J ournal of E conomics, 1999, 30, 232-262. 
— and J ean Tirole, "The Politics of Decision-M aking: Regulatory Institutions," J ournal of Law E conomics and Organization, 1990, 6, 1-32.

_ and _ _ "The Politics of Government Decision-M aking: a Theory of R egulatory Capture," Quarterly J ournal of E conomics, 1991, 106, 1089-1127.

_ and _ _ A Theory of Incentives in Procurement and Regulation, Cambridge M A: MIT Press, 1993.

Levy, Brian and Pablo Spiller, Regulations, Institutions and Commitment, Cambridge: Cambridge University Press.

Li, Wei, Christine Zhen-Wei Qiang, and Lixin Colin Xu, "The Political Economy of Privatisation and Competition: Cross-C ountry Evidence from the Telecommunications Sector," mimeo, World Bank and Virginia University 2001.

Lijphart, A rend, Patterns of Democracy, New Haven and London: Yale University Press.

Limdep, User's Manual, Version 7.0 1999. Econometric Software.

Lizzeri, A lessandro and Nicola Perisco, "The Provision of P ublic Goods under A Iternative Electoral Incentives," A merican Economic Review, 2001, 91, 225-239.

Long, Scott J ., Regression M odels for C ategorical and Limited Dependent Variables, Thousand Oaks, CA: SAGE Publications, 1997.

M addala, G.S., Limited-Dependent and Qualitative Variables in Econometrics, Cambridge: Cambridge University Press, 1987.

McCubbins, Mathew D., Roger G. Noll, and Barry R. Weingast, "Structure and Process, Politics and Policy: Administrative Arrangements and the Political control of Agencies," Virginia Law Review, 1989, 75, 431-482.

M ilesi-Ferretti, Gian-Maria, Roberto Perotti, and Massimo Rostagno, "Electoral Rules and Public Spending," Discussion Paper No. 2742, CEPR 2001.

N even, Damien, R obin Nuttal, and Paul Seabright, Mergers in Daylight. The E conomics and Policy of Merger control in the EC, L ondon: CEPR, 1993.

Nicoletti, Giuseppe, "R egulation in Services: OECD Patterns and E conomic I mplications," Economics Department Working Paper, No. 278, OECD, Paris 2001.

Noll, R oger, "Economic Perspectives on the Politics of Regulation," in R. Schmalansee and R.D. Willig, eds., Handbook of Industrial O rganization, 1989. 
— . "Telecommunications R eform in Developing Countries," in A nne O. K rueger, ed., Economic and Policy Reform: The Second Stage, Chicago: University of Chicago Press, 2001.

OECD, "Regulatory Reform in Network Industries: Past Experience and Current Issues," in "OECD Economic Outlook No. 67" 2000.

Olson, M ancur, The Logic of Collective Action, Cambridge, MA: Harvard University Press, 1965.

Peltzman, Sam, "Toward a More General Theory of Regulation," J ournal of Law and Economics, 1976, 19, 211-240.

— , "T he Economic Theory of R egulation after a Decade of Deregulation," Brookings papers in Economic Activity: Microeconomics, 1989, Special I ssue, 1-41.

Persson, Torsten, "Do Political Institutions Shape Economic Policy?," Econometrica, 2001, for thcoming.

- and Guido Tabellini, "The Size and Scope of Government: Comparative Politics with Rational Politicians. 1998 Marshall Lecture," European Economic Review, 1999, 43, 699735.

— and _ , Political Economics. Explaining Economic Policy, Cambridge MA: MIT Press, 2000.

— and _ - "Political Institutions and Policy Outcomes: What are the Stylized Facts?," mimeo, Stockholm and M ilan 2001.

, Gerard R oland, and Guido Tabellini, "Separation of Powers and Political Accountability," Quarterly J ournal of Economics, 1997, 112, 1163-1202.

Poole, K eith T. and Howard R osenthal, "The enduring nineteenth-century battle for economic regulation: the Interstate Commerce Act revisited," The J ournal of Law and Economics, 1993, 36, 837-860.

Potters, J an and Randolph Sloof, "Interest Groups: A Survey of Empirical M odels That Try to A ssess Their Infuence," European J ournal of Political E conomy, 1996, 12, 403-442.

Pryor, Frederic L., "Quantitative Notes on T he Extent of Governmental Regulations in Various OECD Nations," mimeo, Swarthmore College 2000. 
Romer, Thomas and Howard R osenthal, "Modern Political Economy and the Study of Regulation," in Elisabeth Bailey, ed., Public Regulation, Cambridge, M A: MIT P ress, 1987, pp. 73-116.

Spiller, Pablo T., "Politicians, Interest Groups, and Regulators: A M ultiple-P rincipals A gency Theory of Regulation, or "Let Them B e Bribed," J ournal of Law and Economics, 1990, 33, 65-101.

Stata, U ser's Manual, Version 7.0 2001. Econometric Software.

Stigler, George, "The Theory of E conomic Regulation," The B ell J ournal of Economics, 1971, pp. 3-21.

Tsebelis, George, "Decision Making in Political Systems: Veto Players in Presidentialism, Parliamentarism, Muliticameralism and Multipartyism," British J ournal of Political Science, 1995, 25, 289-325.

Winston, Clixord, "Economic Deregulation: Days of Reckoning for Microeconomists," J ournal of E conomic Literature, 1993, 31, 1263-89.

Woldendorp, J aap, Hans K eman, and Ian Budge, "Party government in 20 democracies: an update (1990-1995)," European J ournal of Political Research, 1998, 33, 125-164. 


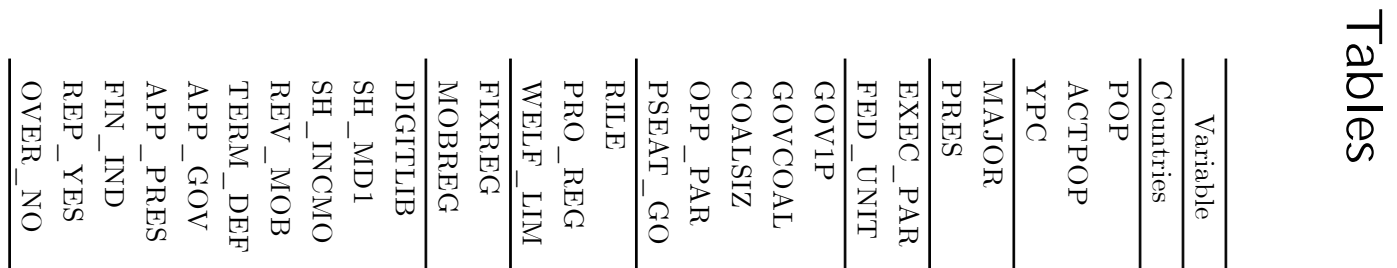

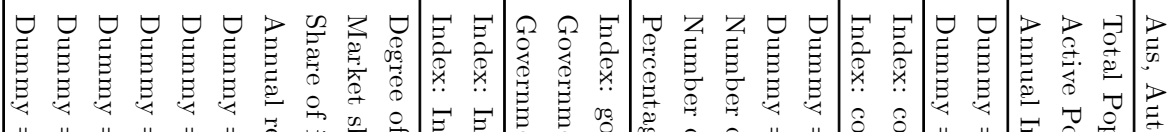

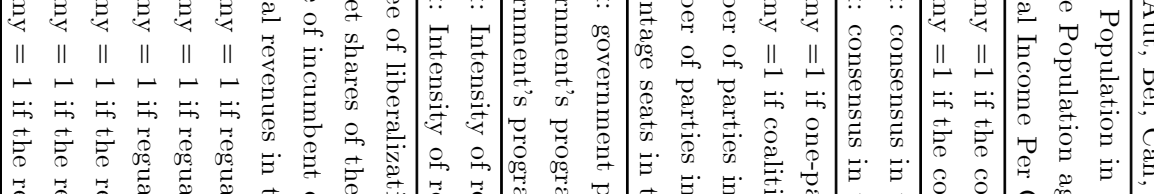

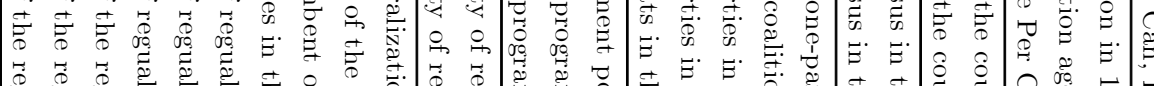

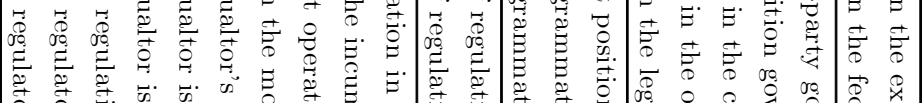

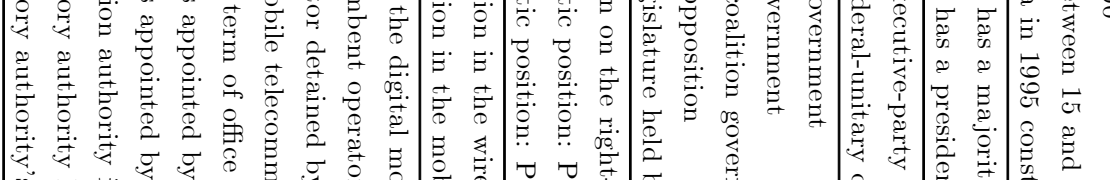

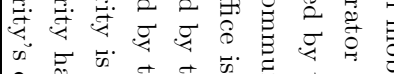

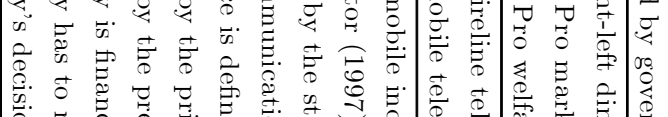

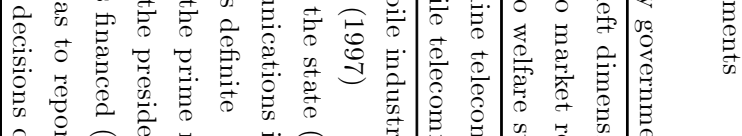

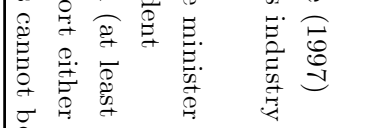

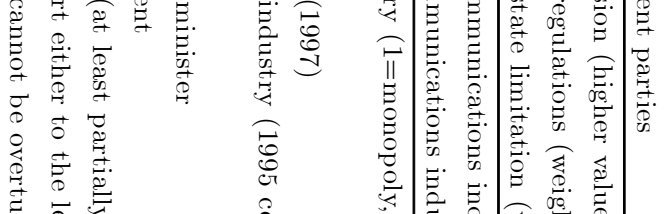

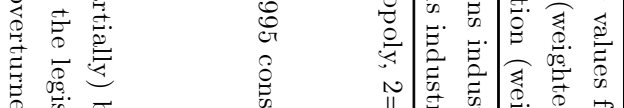

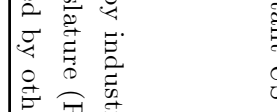

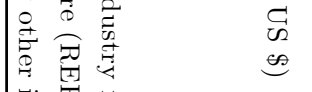

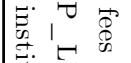

可

है.

o

官

:

움

점

狊
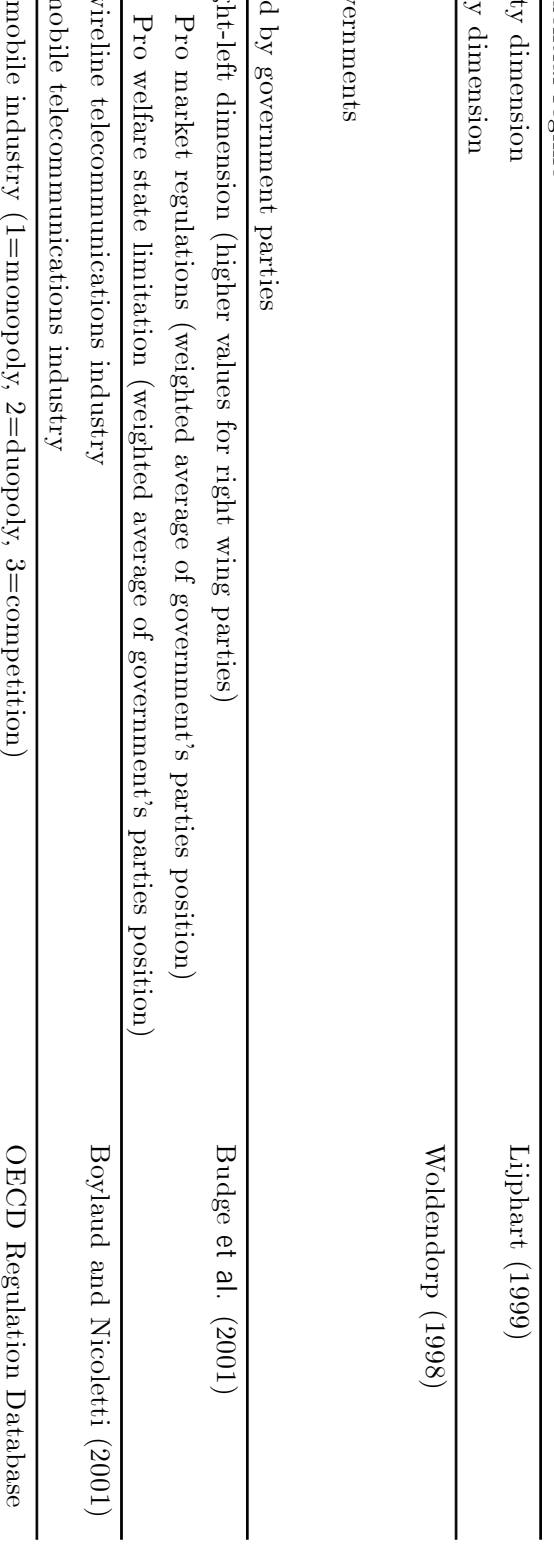

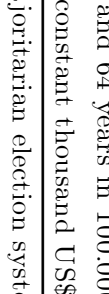

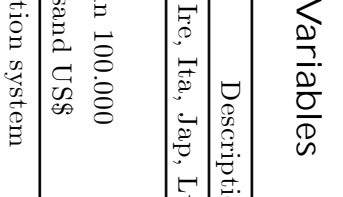


Table 1b. P reliminary Statistics

\begin{tabular}{lrrrrr}
\multicolumn{1}{c}{ Variable } & \multicolumn{1}{c}{ Mean } & Std.Dev. & \multicolumn{1}{c}{ Min. } & \multicolumn{1}{c}{ Max. } & Cases \\
\hline POP & 483.7358 & 712.0181 & 3.8980 & 2667.9200 & 168 \\
ACTPOP & 321.9546 & 469.4767 & 2.6810 & 1753.5700 & 168 \\
YPC & 19.5914 & 10.8051 & 0.1338 & 43.8045 & 168 \\
\hline MAJOR & 0.2500 & 0.4343 & 0.0000 & 1.0000 & 168 \\
PRES & 0.0830 & 0.2772 & 0.0000 & 1.0000 & 168 \\
EXEC_PAR & 0.2062 & 1.0123 & -1.4700 & 1.8700 & 168 \\
FED_UNIT & 0.1075 & 1.1564 & -1.7700 & 2.5300 & 168 \\
\hline GOVCOAL & 0.5714 & 0.4964 & 0.0000 & 1.0000 & 168 \\
GOVIP & 0.4226 & 0.4955 & 0.0000 & 1.0000 & 168 \\
COALSIZ & 1.9702 & 1.1706 & 1.0000 & 5.0000 & 168 \\
OPP_PAR & 4.1607 & 2.0248 & 1.0000 & 10.0000 & 168 \\
PSEAT_GO & 54.8373 & 12.3712 & 13.9881 & 85.6152 & 168 \\
RILE & 1.0036 & 18.5006 & -37.2595 & 48.7013 & 168 \\
PRO_REG & 1.7701 & 1.5668 & 0.0000 & 6.2500 & 168 \\
WELF_LIM & 0.4470 & 0.8881 & 0.0000 & 4.200 & 168 \\
\hline FIXREG & 0.4479 & 0.2331 & 0.1742 & 0.8814 & 168 \\
MOBREG & 0.6065 & 0.2154 & 0.1590 & 0.9529 & 168 \\
DIGITLIB & 2.0476 & 0.8175 & 1.0000 & 3.0000 & 168 \\
SH_MD1 & 62.9000 & 22.2988 & 0.0000 & 100.0000 & 161 \\
SH_INCMO & 56.8308 & 32.4556 & 0.0000 & 100.0000 & 91 \\
REV_MOB & $0.1 E+13$ & $0.7 E+13$ & $0.1 E+08$ & $0.9 E+14$ & 146 \\
TERM_DEF & 0.6667 & 0.4728 & 0.0000 & 1.0000 & 168 \\
APP_GOV & 0.2917 & 0.4559 & 0.0000 & 1.0000 & 168 \\
APP_PRES & 0.1667 & 0.3738 & 0.0000 & 1.0000 & 168 \\
FIN_IND & 0.6667 & 0.4728 & 0.0000 & 1.0000 & 168 \\
REP_YES & 0.7500 & 0.4343 & 0.0000 & 1.0000 & 168 \\
REP_LEG & 0.2500 & 0.4343 & 0.0000 & 1.0000 & 168 \\
REP_MIN & 0.5000 & 0.5015 & 0.0000 & 1.0000 & 168 \\
OVER_NO & 0.7083 & 0.4559 & 0.0000 & 1.0000 & 168 \\
\hline & & & & &
\end{tabular}




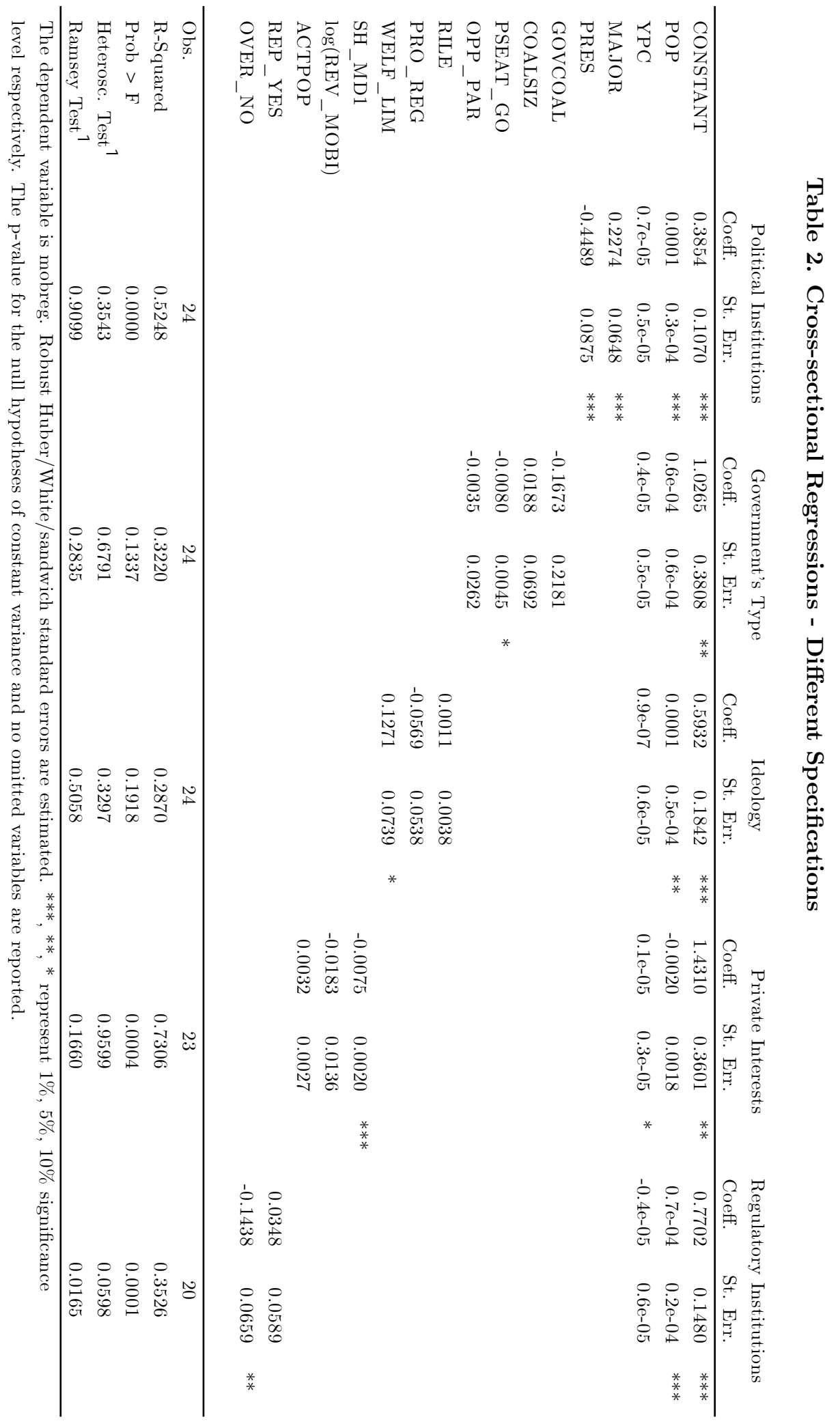


Table 3. Panel Regressions - Ordered Probit with Random Effects Political Institutions

\begin{tabular}{|c|c|c|c|c|c|c|c|c|c|}
\hline & \multicolumn{3}{|c|}{ Specification 1} & \multicolumn{3}{|c|}{ Specification 2} & \multicolumn{3}{|c|}{ Specification 3} \\
\hline & Coeff. & St.Err. & & Coeff. & St.Err. & & Coeff. & St.Err. & \\
\hline Constant & -3.2341 & 0.9394 & $* * *$ & -0.8064 & 0.7230 & & -1.7926 & 1.1150 & $*$ \\
\hline YPC & -0.0006 & 0.0341 & & -0.0021 & 0.0392 & & 0.0012 & 0.0247 & \\
\hline POP & 0.0008 & 0.0007 & & 0.0019 & 0.0011 & $*$ & -0.0005 & 0.0024 & \\
\hline TIME_IND & 1.0339 & 0.2237 & $* * *$ & 0.9886 & 0.1791 & $* * *$ & 1.0577 & 0.2731 & $* * *$ \\
\hline MAJOR & 8.5218 & 1.8994 & $* * *$ & & & & 12.1643 & 2.5255 & $* * *$ \\
\hline PRES & -3.6621 & 4.7755 & & & & & -0.4212 & 5.8852 & \\
\hline EXEC_PAR & & & & -1.6410 & 0.4109 & $* * *$ & -0.4970 & 0.9035 & \\
\hline FED_UNIT & & & & -0.9808 & 0.3836 & $* * *$ & -2.3829 & 0.9253 & $* * *$ \\
\hline $\mathrm{Mu}(01)$ & 4.9791 & 0.9188 & $* * *$ & 4.6056 & 0.7763 & $* * *$ & 4.9582 & 1.0905 & $* * *$ \\
\hline Sigma & 4.2509 & 0.8551 & $* * *$ & 4.7398 & 0.7971 & $* * *$ & 4.4729 & 1.3397 & $* * *$ \\
\hline N. obs. & & 168 & & & 168 & & & 168 & \\
\hline Log likelihood & & -69.8868 & & & 74.5568 & & & 73.6207 & \\
\hline Pseudo $\mathrm{R}^{2}$ & & 0.4213 & & & 0.3826 & & & 0.3904 & \\
\hline
\end{tabular}

The dependent variable is DIGITLIB. ${ }^{* * *},{ }^{* *},{ }^{*}$ represents $1 \%, 5 \%$, and $10 \%$ significance level respectively.

Table 4. Panel Regressions - Ordered Probit with Random Effects Government's Types

\begin{tabular}{|c|c|c|c|c|c|c|}
\hline & \multicolumn{3}{|c|}{ Specification 1} & \multicolumn{3}{|c|}{ Specification 2} \\
\hline & Coeff & St.Err. & & Coeff & St.Err. & \\
\hline Constant & -0.6484 & 0.5205 & & -1.8984 & 1.2529 & \\
\hline YPC & -0.0007 & 0.0243 & & -0.0017 & 0.0266 & \\
\hline $\mathrm{POP}$ & 0.0011 & 0.0006 & $*$ & 0.0020 & 0.0010 & * \\
\hline TIME_IND & 1.0499 & 0.2470 & $* * *$ & 1.1527 & 0.3839 & $* * *$ \\
\hline GOVCOAL & -3.2626 & 1.2434 & $* * *$ & -6.6540 & 2.8610 & $* *$ \\
\hline COALSIZ & 0.3642 & 0.2671 & & 1.7623 & 0.9235 & $*$ \\
\hline PSEAT_GO & & & & 0.0112 & 0.0123 & \\
\hline OPP_PAR & & & & 0.0791 & 0.1319 & \\
\hline $\mathrm{Mu}(01)$ & 4.8461 & 0.9502 & $* * *$ & 5.5793 & 1.7723 & $* *$ \\
\hline Sigma & 4.9484 & 1.1164 & $* * *$ & 4.9088 & 1.4133 & $* * *$ \\
\hline Obs. & & 168 & & & 168 & \\
\hline Log likelihood & & 73.5973 & & & 72.6033 & \\
\hline Pseudo $\mathrm{R}^{2}$ & & 0.3905 & & & 0.3988 & \\
\hline Chi-squared & & 68.5929 & & & 57.5847 & \\
\hline
\end{tabular}

The dependent variable is DIGITLIB. ${ }^{* * *},{ }^{* *},{ }^{*}$ represents $1 \%, 5 \%$, and $10 \%$ significance level respectively. 
Table 5. Panel Regressions - Ordered Probit with Random Effects Ideology and Programmatic Positions

\begin{tabular}{|c|c|c|c|c|c|c|c|c|c|}
\hline \multirow{3}{*}{ CONSTANT } & \multicolumn{3}{|c|}{ Specification 1} & \multicolumn{3}{|c|}{ Specification 2} & \multicolumn{3}{|c|}{ Specification 3} \\
\hline & \multirow{2}{*}{$\begin{array}{c}\text { Coeff. } \\
-0.1604\end{array}$} & \multicolumn{2}{|l|}{ St. Err. } & \multirow{2}{*}{$\frac{\text { Coeff. }}{-1.7350}$} & \multicolumn{2}{|l|}{ St. Err. } & \multirow{2}{*}{$\begin{array}{c}\text { Coeff. } \\
-0.7505\end{array}$} & \multicolumn{2}{|l|}{ St. Err. } \\
\hline & & 0.7566 & & & 1.0485 & $*$ & & 1.1732 & \\
\hline YPC & -0.0007 & 0.0231 & & 0.0014 & 0.0131 & & 0.0005 & 0.0069 & \\
\hline POP & 0.0009 & 0.0007 & & 0.0002 & 0.0008 & & 0.0006 & 0.0011 & \\
\hline TIME_IND & 1.0875 & 0.2337 & $* * *$ & 1.1229 & 0.3704 & $* * *$ & 1.3096 & 0.7203 & * \\
\hline RILE & 0.0281 & 0.0121 & $* *$ & & & & 0.0181 & 0.0168 & \\
\hline PRO_REG & & & & -0.5237 & 0.1658 & $* * *$ & -0.7271 & 0.3032 & $* * *$ \\
\hline WELF_LIM & & & & 1.2390 & 0.5131 & $* *$ & 1.2391 & 0.7905 & \\
\hline $\mathrm{Mu}(01)$ & 5.3502 & 0.9540 & $* * *$ & 5.3282 & 1.4410 & $* * *$ & 6.3057 & 3.0396 & $* *$ \\
\hline Sigma & 4.8138 & 0.9345 & $* * *$ & 6.7647 & 1.7510 & $* * *$ & 5.2732 & 2.5727 & $* *$ \\
\hline Obs. & & 168 & & & 168 & & & 168 & \\
\hline Log likelihood & & -73.5089 & & & -65.2567 & & & -67.2168 & \\
\hline Pseudo $\mathrm{R}^{2}$ & & 0.3913 & & & 0.4596 & & & 0.4434 & \\
\hline Chi-squared & & 177.4725 & & & 176.9574 & & & 172.8027 & \\
\hline
\end{tabular}

Table 6. Panel Regressions - Ordered Probit with Random Effects Private Interests

\begin{tabular}{|c|c|c|c|c|c|c|c|c|c|}
\hline & \multicolumn{3}{|c|}{ Specification 1} & \multicolumn{3}{|c|}{ Specification 2} & \multicolumn{3}{|c|}{ Specification 3} \\
\hline & Coeff. & St. Err. & & Coeff. & St. Err. & & Coeff. & St. Err. & \\
\hline CONSTANT & 14.4126 & 4.2054 & *** & 12.6041 & 4.1404 & $* * *$ & 12.0266 & 5.6756 & $* *$ \\
\hline YPC & -0.0007 & 0.0209 & & -0.0008 & 0.0482 & & -0.0007 & 0.018 & \\
\hline POP & 0.0010 & 0.0026 & & 0.0003 & 0.0029 & & 0.0002 & 0.0065 & \\
\hline TIME_IND & 1.1187 & 0.3461 & $* * *$ & 1.1557 & 0.5064 & $* *$ & 1.1845 & 0.3837 & $* * *$ \\
\hline $\mathrm{SH} \_\mathrm{MD} 1$ & -0.1100 & 0.0283 & $* * *$ & -0.1441 & 0.0464 & $* * *$ & -0.1207 & 0.0384 & $* * *$ \\
\hline $\log \left(\mathrm{REV} \_\mathrm{MOB}\right)$ & -0.4394 & 0.1890 & & -0.2021 & 0.1771 & & -0.3156 & 0.2910 & \\
\hline ACTPOP & 0.0005 & 0.0037 & & 0.0006 & 0.0040 & & 0.0014 & 0.0112 & \\
\hline FIN_IND & & & & -2.1413 & 1.1814 & $* * *$ & 0.9685 & 0.9539 & \\
\hline SH_INCMO & & & & & & & 0.0011 & 0.0010 & \\
\hline $\mathrm{Mu}(01)$ & 4.7650 & 1.1702 & $* * *$ & 5.2609 & 1.6245 & $* *$ & 5.4180 & 1.4459 & $* * *$ \\
\hline Sigma & 4.2537 & 1.0094 & $* * *$ & 4.5580 & 1.8092 & $* *$ & 4.9174 & 1.2013 & $* * *$ \\
\hline Obs. & & 139 & & & 139 & & & 139 & \\
\hline Log likelihood & & -61.8721 & & & -60.2144 & & & -59.2535 & \\
\hline Pseudo $\mathrm{R}^{2}$ & & 0.3804 & & & 0.3970 & & & 0.4066 & \\
\hline Chi-squared & & 120.6920 & & & 21.7747 & & & 122.2870 & \\
\hline
\end{tabular}


Table 7. Panel Regressions - Ordered Probit with Random Effects Regulatory Institutions

\begin{tabular}{|c|c|c|c|c|c|c|c|c|c|}
\hline \multirow{3}{*}{ CONSTANT } & \multicolumn{3}{|c|}{ Specification 1} & \multicolumn{3}{|c|}{ Specification 2} & \multicolumn{3}{|c|}{ Specification 3} \\
\hline & \multirow{2}{*}{$\begin{array}{c}\text { Coeff. } \\
-6.9842\end{array}$} & \multicolumn{2}{|l|}{ St. Err. } & \multirow{2}{*}{$\frac{\text { Coeff. }}{-6.5866}$} & \multicolumn{2}{|l|}{ St. Err. } & \multirow[b]{2}{*}{-15.2353} & \multirow[b]{2}{*}{4.3514} & \multirow[b]{2}{*}{$* * *$} \\
\hline & & 2.3154 & $* * *$ & & 3.8273 & $*$ & & & \\
\hline YPC & -0.0029 & 0.0619 & & -0.0013 & 0.0488 & & -0.0046 & 0.0854 & \\
\hline POP & 0.0026 & 0.0016 & $*$ & 0.0016 & 0.0023 & & 0.0042 & 0.0018 & $* *$ \\
\hline TIME_IND & 1.0531 & 0.2148 & $* * *$ & 1.0617 & 0.3480 & $* * *$ & 1.0847 & 0.3190 & $* * *$ \\
\hline REP_LEG & 6.9991 & 2.2797 & $* * *$ & 2.7693 & 1.7634 & & 8.5697 & 3.4029 & $* *$ \\
\hline REP_MIN & 6.6765 & 2.0772 & $* * *$ & 6.8230 & 2.4643 & $* * *$ & 15.2268 & 4.1670 & $* * *$ \\
\hline OVER_NO & -0.2902 & 0.7754 & & -0.7240 & 1.6595 & & -4.3335 & 2.4022 & $* *$ \\
\hline APP_GOV & & & & 3.5282 & 1.4275 & $* *$ & 7.1314 & 3.0020 & $* *$ \\
\hline APP_PRES & & & & 4.7662 & 1.4327 & $* * *$ & 5.8261 & 2.5710 & $* *$ \\
\hline TERM_DEF & & & & & & & -0.0094 & 0.0040 & $* *$ \\
\hline $\mathrm{Mu}(01)$ & 5.0144 & 0.9222 & $* * *$ & 4.9942 & 1.3628 & $* * *$ & 5.0983 & 1.1394 & $* * *$ \\
\hline Sigma & 4.8900 & 1.0709 & $* * *$ & 5.1562 & 1.3399 & $* * *$ & 5.5877 & 1.7546 & $* * *$ \\
\hline Obs. & & 168 & & & 168 & & & 168 & \\
\hline Log likelihood & & -67.2545 & & & -67.7132 & & & 5.7883 & \\
\hline Pseudo $\mathrm{R}^{2}$ & & 0.4431 & & & 0.4393 & & & 4552 & \\
\hline Chi-squared & & 135.4026 & & & 132.2688 & & & 8.0623 & \\
\hline
\end{tabular}




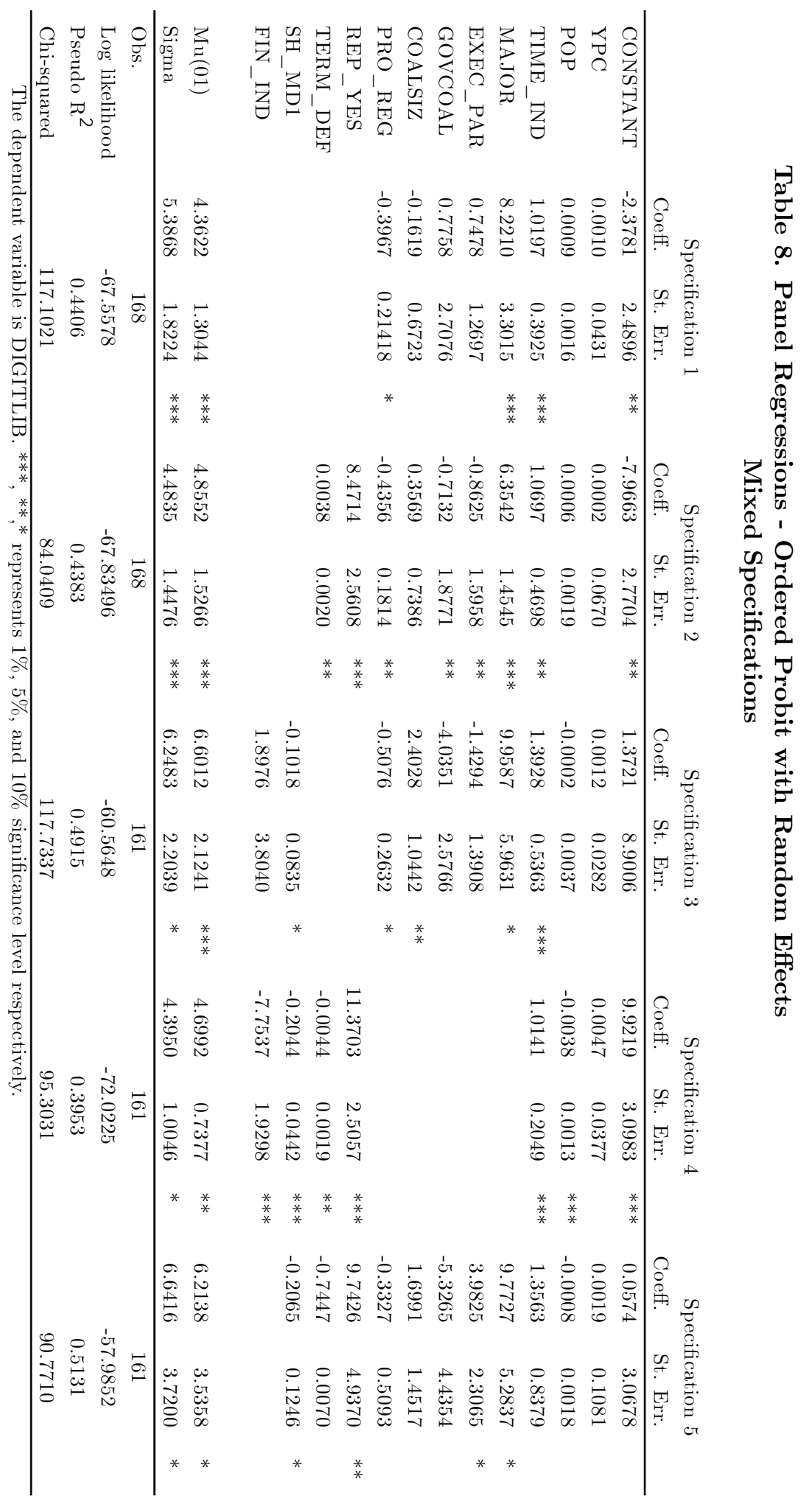


Bücher des Forschungsschwerpunkts Markt und politische Ökonomie

Books of the Research Area Markets and Political Economy

(nur im Buchhandel erhältlich/available through bookstores)

Andreas Stephan

Essays on the Contribution of Public Infrastructure to Private: Production and its Political

Economy

2002, dissertation.de

Hans Mewis

Essays on Herd Behavior and Strategic

Delegation

2001, Shaker Verlag

Andreas Moerke

Organisationslernen über Netzwerke - Die

personellen Verflechtungen von

Führungsgremien japanischer

Aktiengesellschaften

2001, Deutscher Universitäts-Verlag

Silke Neubauer

Multimarket Contact and Organizational Design

2001, Deutscher Universitäts-Verlag

Lars-Hendrik Röller, Christian Wey (Eds.)

Die Soziale Marktwirtschaft in der neuen

Weltwirtschaft, WZB Jahrbuch 2001

2001, edition sigma

Michael Tröge

Competition in Credit Markets: A Theoretic

Analysis

2001, Deutscher Universitäts-Verlag

Tobias Miarka

Financial Intermediation and Deregulation:

A Critical Analysis of Japanese Bank-Firm-

Relationships

2000, Physica-Verlag

Damien J. Neven, Lars-Hendrik Röller (Eds.)

The Political Economy of Industrial Policy in Europe and the Member States

2000, edition sigma

Jianping Yang

Bankbeziehungen deutscher Unternehmen: Investitionsverhalten und Risikoanalyse

2000, Deutscher Universitäts-Verlag

Horst Albach, Ulrike Görtzen, Rita Zobel (Eds.)

Information Processing as a Competitive

Advantage of Japanese Firms

1999, edition sigma

Dieter Köster

Wettbewerb in Netzproduktmärkten

1999, Deutscher Universitäts-Verlag

Christian Wey

Marktorganisation durch Standardisierung: Ein

Beitrag zur Neuen Institutionenökonomik des

Marktes

1999, edition sigma
Horst Albach, Meinolf Dierkes, Ariane Berthoin Antal, Kristina Vaillant (Hg.)

Organisationslernen - institutionelle und

kulturelle Dimensionen

WZB-Jahrbuch 1998

1998, edition sigma

Lars Bergman, Chris Doyle, Jordi Gual, Lars

Hultkrantz, Damien Neven, Lars-Hendrik Röller,

Leonard Waverman

Europe's Network Industries: Conflicting

Priorities - Telecommunications

Monitoring European Deregulation 1

1998, Centre for Economic Policy Research

Manfred Fleischer

The Inefficiency Trap

Strategy Failure in the

German Machine Tool Industry

1997, edition sigma

Christian Göseke

Information Gathering and Dissemination

The Contribution of JETRO to

Japanese Competitiveness

1997, Deutscher Universitäts-Verlag

Andreas Schmidt

Flugzeughersteller zwischen globalem

Wettbewerb und internationaler Kooperation

Der Einfluß von Organisationsstrukturen auf die

Wettbewerbsfähigkeit von Hochtechnologie-

Unternehmen

1997, edition sigma

Horst Albach, Jim Y. Jin, Christoph Schenk (Eds.)

Collusion through Information Sharing?

New Trends in Competition Policy

1996, edition sigma

Stefan O. Georg

Die Leistungsfähigkeit japanischer Banken

Eine Strukturanalyse des Bankensystems in

Japan

1996, edition sigma

Stephanie Rosenkranz

Cooperation for Product Innovation

1996, edition sigma

Horst Albach, Stephanie Rosenkranz (Eds.)

Intellectual Property Rights and Global

Competition - Towards a New Synthesis

1995, edition sigma

David B. Audretsch

Innovation and Industry Evolution

1995, The MIT Press 
Julie Ann Elston

US Tax Reform and Investment: Reality and Rhetoric in the 1980s

1995, Avebury
Horst Albach

The Transformation of Firms and Markets:

A Network Approach to Economic Transformation Processes in East Germany

Acta Universitatis Upsaliensis, Studia Oeconomiae Negotiorum, Vol. 34

1994, Almqvist \& Wiksell International (Stockholm) 
Fredrik Andersson

Kai A. Konrad

Andreas Stephan

Tomaso Duso

Steffen Huck

Kai A. Konrad

Wieland Müller

Steffen Huck

Kai A. Konrad

Wieland Müller

Jos Jansen

Astrid Jung

Jonas Björnerstedt Johan Stennek

Manfred Fleischer

Karl Wärneryd

Karl Wärneryd

Steffen Huck

Kai A. Konrad

Michal Grajek

Achim Kemmerling

Andreas Stephan

Suchan Chae

Paul Heidhues

Kai A. Konrad Harald Künemund Kjell Erik Lommerud Julio R. Robledo

Tomaso Duso Lars-Hendrik Röller
Globalization and Human Capital Formation

FS IV $01-01$

Regional Infrastructure Policy and its Impact

FS IV $01-02$ on Productivity: A Comparison of Germany and France

Lobbying and Regulation in a Political Economy: FS IV $01-03$ Evidence from the US Cellular Industry

Merger and Collusion in Contest

FS IV $01-04$

Profitable Horizontal Mergers without Cost

Advantages: The Role of Internal Organization,

Information, and Market Structure

Strategic Information Revelation and Revenue

Sharing in an R\&D Race

(A revision of FS IV 99-11)

FS IV $01-05$

FS IV $01-06$

FS IV $01-07$

Complements?

Bilateral Oligopoly

FS IV $01-08$

Regulierungswettbewerb und Innovation in der chemischen Industrie

FS IV $01-09$

FS IV $01-10$

Preference Adaptation in Winner-Take-All Markets

Information in Conflicts

FS IV $01-11$

FS IV $01-12$

Merger Profitability and Trade Policy

Gender Pay Gap in Poland

FS IV $01-13$

FS IV $01-14$

The Contribution of Local Public Infra-structure to Private Productivity and its Political-Economy: Evidence from a Panel of Large German Cities

Nash Bargaining Solution with Coalitions and the Joint Bargaining Paradox

Geography of the Family

FS IV $01-15$

FS IV $01-16$

Towards a Political Economy of Industrial OrganFS IV $01-17$ ization: Empirical Regularities from Deregulation 
Kai A. Konrad

Roman Inderst Christian Wey

Kai A. Konrad

Helmut Seitz

Klaus Gugler Dennis C. Mueller B. Burcin Yurtoglu Christine Zulehner

Kjell Erik Lommerud Odd Rune Straume Lars Sørgard

Andreas Blume Paul Heidhues

Roman Inders Christian Wey

Klaus Gugler Dennis C. Mueller B. Burcin Yurtoglu

Sven-Olof Fridolfsson Johan Stennek
Investment in the Absence of Property Rights - The Role of Incumbency Advantages

Bargaining, Mergers, and Technology Choice in Bilaterally Oligopolistic Industries

Fiscal Federalism and Risk Sharing in Germany: The Role of Size Differences

The Effects of Mergers: An International Comparison

Downstream Merger with Oligopolistic Input FS IV 01-22 Suppliers

Tacit Collusion in Repeated Auctions

The Incentives for Takeover in Oligopoly

Corporate Governance, Capital Market Discipline and the Returns on Investment

Why Mergers Reduce Profits and Raise Share Prices: A Theory of Preemptive Mergers
FS IV $01-23$

FS IV $01-24$

FS IV $01-18$

FS IV $01-19$

FS IV $01-20$

FS IV $01-21$

FS IV $01-25$

FS IV $01-26$ 
Fredrik Andersson Kai A. Konrad

Lars-Hendrik Röller

Christian Wey

Talat Mahmood Klaus Schömann

Jos Jansen

Jos Jansen

Günter Franke Harris Schlesinger Richard C. Stapleton

Tomaso Duso
Human Capital Investment and Globalization in Extortionary States

Merger Control in the New Economy

Die Determinanten der Mirgrationsentscheidung von IT-Hochschulabsolventen aus Pakistan Empirische Befunde zur Ausgestaltung der deutschen „Green Card“"

The Effects of Disclosure Regulation on Innovative Firms: Common Values

The Effects of Disclosure Regulation on Innovative Firms: Private Values

Multiplicative Background Risk

On the Politics of the Regulatory Reform: Econometric Evidence from the OECD Countries
FS IV $02-06$

FS IV $02-01$

FS IV $02-02$

FS IV $02-03$

FS IV $02-04$

FS IV $02-05$

FS IV $02-07$ 

Bei Ihren Bestellungen von WZB-Papers schicken

Sie bitte unbedingt einen an Sie adressierten Auf-

kleber mit sowie je paper eine Briefmarke im Wert

von 0,51 Euro oder einen "Coupon Reponse Inter-

national " (für Besteller aus dem Ausland)
Please send a self addressed label and postage stamps in the amount of 0.51 Euro or a "CouponReponse International" (if you are ordering from outside Germany) for each WZB-paper requested

Absender / Return Address:

Wissenschaftszentrum Berlin

für Sozialforschung

Presse- und informationsreferat

Reichpietschufer 50

D-10785 Berlin-Tiergarten

Hiermit bestelle ich folgende(s)

Discussion paper(s):

Please send me the following Discussion paper(s):

Bestell-Nr. / Order no.

Autor/in, Kurztitel /Author(s) / Title(s) in brief 